\title{
12. NANNOFOSSIL BIOSTRATIGRAPHY, LEG 20, DEEP SEA DRILLING PROJECT ${ }^{1}$
}

\author{
Heinz Hekel, Geological Survey of Queensland, Brisbane, Australia
}

\begin{abstract}
Nannofossil assemblages from five sites of Leg 20, between Japan and the Caroline Islands, indicate an age range of early Cretaceous to Pleistocene for the sediments recovered (Figure 1). The assemblages have been assigned to 24 zones and "zonal intervals;" (Table 1) Nannofossils have also been used to estimate the extent of reworking. Sedimentation rates, based on nannofossil zone boundaries, have been estimated. Selected species are illustrated by light and electron-photomicrographs to assist species interpretation and the state of preservation of the fossils.
\end{abstract}

\section{INTRODUCTION}

In the course of Leg 20 of the Deep Sea Drilling Project, from Yokohama to Fiji, 58 cores were recovered from eight sites. Approximately 250 samples have been examined for nannofossils. The water depth at all sites, except the last two (on a seamount), is about 6000 meters. This is far below the carbonate compensation depth; consequently, no calcareous nannoplankton can be expected to be preserved during time intervals with low sedimentation rates similar to present-day conditions. Thus cores from Sites 194, 197 (only basalt recovered), 198, and the upper parts of 195 and 196 are barren of nannofossils. The rapid deposition of the turbidite section of 199 , on the other hand, led to the preservation of nannofossils, despite the water depth of 6100 meters.

The chalk-chert sections in the lower parts of Sites 195, 196, and 199 contain abundant nannofossils, indicating a different environment of deposition. Sediments from the lower part of the section from Ita Mai Tai Seamount, now at a depth of about 1500 meters, contain oolites, indicating that they were originally deposited close to the surface.

Practically all calcareous samples are fossiliferous. The state of preservation permits age determinations to within the limits of one or two nannofossil zones. In several cases nannofossils proved to be the only available fossils for age interpretations.

\section{STRATIGRAPHIC ZONATION}

During the program of the Deep Sea Drilling Project, knowledge of nannofossils typical of different latitudes, and their zonal relationships, has increased rapidly. In this initial report, data available at this stage are used for the documentation and interpretation of the zones in order to provide a basis for compilations of a more regional nature.

Problems limiting the accuracy of the zonation have been experienced in sediments with reworked older fossils

\footnotetext{
${ }^{1}$ Publication authorized by the Under Secretary, Department of Mines, Brisbane.
}

and in winnowed foraminiferal oozes. In some cases only traces of sediment have been recovered. Such low recoveries enhance the possibility of contamination and render difficult any interpretation of sedimentation rates.

The scheme of zones and subzones for the Quaternary, Tertiary, and late Cretaceous as redefined or established by Bukry (1973) and the zonation scheme of Thierstein (1971) for the early Cretaceous are generally followed in this report. In the following discussion the terms zone or subzone are used when adequately diagnostic fossils for the particular zones have been found. In cases where less precise determinations are possible, the assemblages have been assigned to "zonal intervals," comprising two or more of the defined zones.

\section{Discussion of Zones, Subzones, and "Zonal Intervals" as Applied in Leg 20}

The units mentioned below are discussed in descending stratigraphic order. For the ages of these zones, reference should be made to Table 2 .

\section{Emiliania huxleyi Zone}

The base of this zone is characterized by the first occurrence of the living species Emiliania huxleyi. In an electron microscope preparation from Site 200, Core 1, Section 1 (bottom), it was identified in moderate numbers.

\section{Geophyrocapsa oceanica Zone}

The base is indicated by the first occurrence of Geophyrocapsa oceanica (sensu Bukry, 1973). The top is indicated by the first occurrence of Emiliania huxleyi. This zone is represented in Site 200, Core 1, Sections 2 to 4 . The distinction between assemblages assigned to this zone and the Emiliania huxleyi Zone, however, is questionable, because these three samples have not been examined in the electron microscope.

\section{Gephyrocapsa caribbeanica Subzone}

The base is characterized by the first occurrence of Gephyrocapsa caribbeanica and the top by the first 

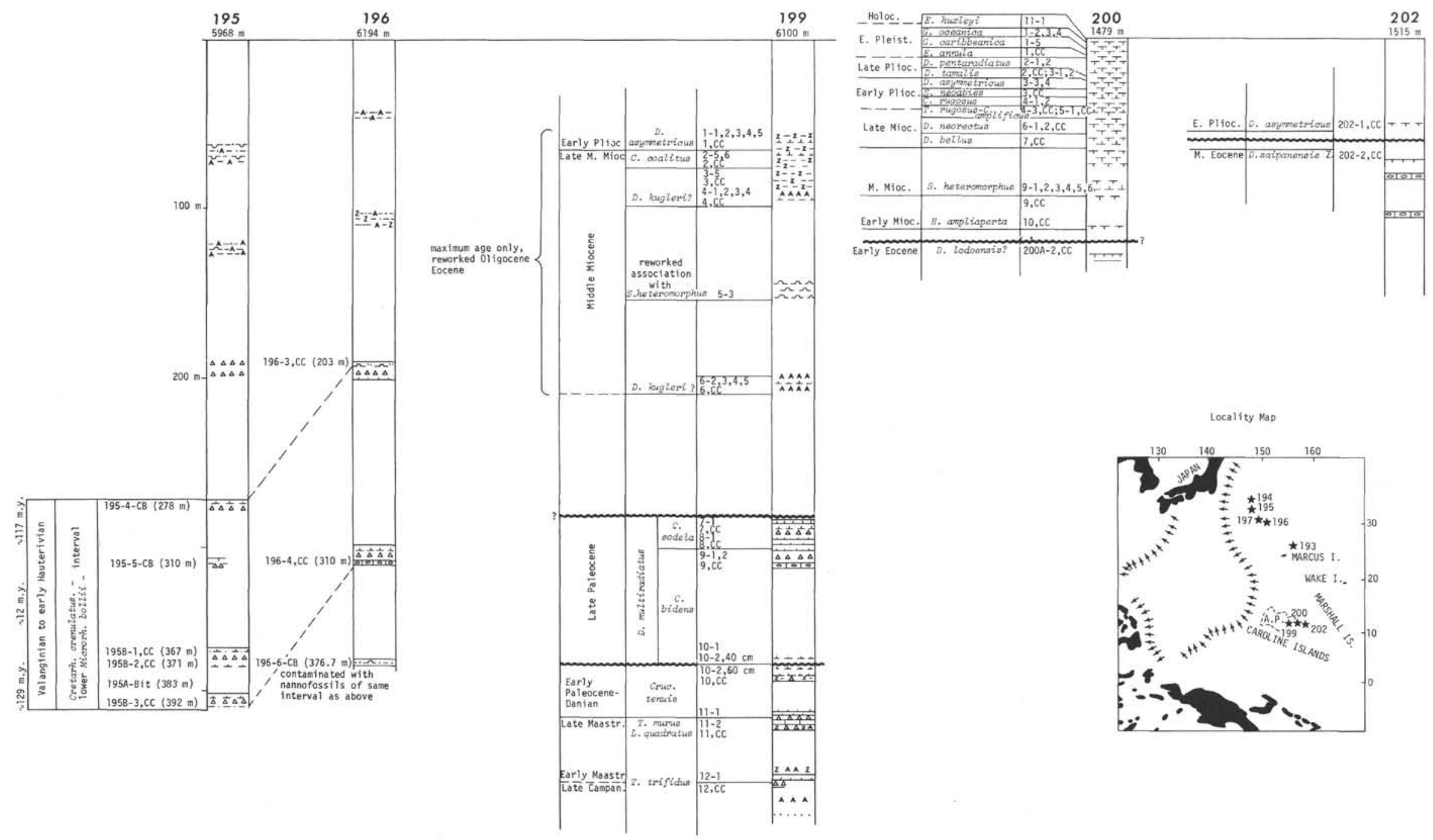

Figure 1. Nannofossil biostratigraphy of Leg 20 drill sites. 
TABLE 1

Zones and "Zonal Intervals" in Leg 20 Cores

\begin{tabular}{|c|c|}
\hline Pleistocene & $\begin{array}{l}\text { Emiliania huxleyi Zone } \\
\text { Gephyrocapsa oceanica Zone } \\
\text { Gephyrocapsa caribbeanica Subzone } \\
\text { Emiliania annula Subzone }\end{array}$ \\
\hline Late Pliocene & $\begin{array}{l}\text { Discoaster pentaradiatus Subzone } \\
\text { Discoaster tamalis Subzone }\end{array}$ \\
\hline Early Pliocene & $\begin{array}{l}\text { Discoaster asymmetricus Subzone } \\
\text { Sphenolithus neoabies Subzone } \\
\text { Ceratolithus rugosus Subzone } \\
\text { Ceratolithus amplificus- } \\
\text { Triquertrorhabdulus rugosus "zonal interval'" }\end{array}$ \\
\hline Late Miocene & $\begin{array}{l}\text { Discoaster neorectus Subzone } \\
\text { Discoaster bellus Subzone }\end{array}$ \\
\hline Middle Miocene & $\begin{array}{l}\text { Catinaster coalitus Zone } \\
\text { ?Discoaster kugleri Subzone } \\
\text { Sphenolithus heteromorphus Zone }\end{array}$ \\
\hline Early Miocene & Helicopontosphaera ampliaperta Zone \\
\hline Middle Eocene & Discoaster saipanensis Subzone \\
\hline Early Eocene & ?Discoaster lodoensis Zone \\
\hline Late Paleocene & $\begin{array}{l}\text { ?Campylosphaera eodela Subzone } \\
\text { Chiasmolithus bidens Subzone }\end{array}$ \\
\hline $\begin{array}{l}\text { Early Paleocene- } \\
\text { Danian }\end{array}$ & Cruciplacolithus tenuis Zone \\
\hline Maastrichtian & $\begin{array}{l}\text { Micula mura-Lithraphidites quadratus } \\
\text { "zonal interval" }\end{array}$ \\
\hline Late Campanian & Tetralithus trifidus Zone \\
\hline $\begin{array}{l}\text { Early Hauterivian- } \\
\text { Valanginian }\end{array}$ & $\begin{array}{l}\text { Microrhabdulus bollii-Cretarhabdus } \\
\text { crenulatus "zonal interval" }\end{array}$ \\
\hline
\end{tabular}

Note: The above are the recognized zones and "zone intervals."

occurrence of $G$. oceanica. This zone is only found in Site 200 , Core 1, Section 5.

\section{Emiliania annula Subzone}

This subzone comprises the interval between the last massive occurrence of Discoaster brouweri (base) and the first occurrence of Geophyrocapsa caribbeanica (top). It is only represented in Site 200 , Core 1 , core catcher. The Cyclococcolithina macintyrei subzone has not been recognized, probably due to poor recovery of Core 2 .

\section{Discoaster pentaradiatus Subzone}

This subzone comprises the interval between the last Discoaster tamalis (base) and the last D. pentaradiatus (top). It is represented in Site 200, Core 2, Sections 1 and 2 .

\section{Discoaster tamalis Subzone}

This subzone comprises the interval between the last Reticulofenestra pseudoumbilica (base) and the last Discoaster tamalis (top). Sphenolithus neoabies and Sphenolithus abies persist in small proportions into this subzone. It is represented in Site 200, Core 3, Section 2 to core catcher.

\section{Discoaster asymmetricus Subzone}

This subzone comprises the interval between the first Discoaster asymmetricus (base) and the last Reticulofenestra pseudoumbilica (top). It is represented in Site 200, Core 3, Sections 3, 4, and core catcher; in Site 200, Core 4, Sections 1, 2; in Site 202, Core 1, core catcher; and in Site 199 , Core 1.

\section{Sphenolithus neoabies Subzone}

This subzone comprises the interval between the last Ceratolithus tricorniculatus (base) and the first consistent appearance of Discoaster asymmetricus (top). It is represented in Site 200, Core 3, core catcher.

\section{Ceratolithus rugosus Subzone}

This subzone comprises the interval between the first occurrence of Ceratolithus rugosus (base) and the last occurrence of $C$. tricorniculatus (top). It is represented in Site 200, Core 4, Sections 1 and 2.

\section{Triquetrorhabdulus rugosus-Ceratolithus amplificus "Zonal-interval"}

This term is here used for the interval between the first occurrence of Ceratolithus tricorniculatus and the first occurrence of C. rugosus. It is represented in Site 200, Core 4 , Section 3 and core catcher, and Site 200, Core 5, Section 1 and core catcher. Differentiation of these two zones has not been attempted.

\section{Discoaster neorectus Subzone}

The base of this subzone is characterized by the first common occurrence of Discoaster brouweri; the top could not be observed as the $D$. berggrenii Zone has not been sampled. The typical species is rather scarce in this section. This subzone is found in Site 200, Core 6, Sections 1, 2, and core catcher.

\section{Discoaster bellus Subzone}

This subzone comprises the interval between the first Discoaster neohamatus (base) and the first $D$. brouweri (top). It is found in Site 200 , Core 7 , core catcher.

\section{Catinaster coalitus Zone}

This zone is characterized by the typical species and is found in Site 199, Core 2, Section 1 to core catcher.

\section{Discoaster kugleri Subzone}

This subzone is characterized by the typical species and by the occurrence of Discoaster bollii. It is found in Site 199 , Core 6.

\section{Sphenolithus heteromorphus Zone}

The base of this zone is characterized by the first appearance of Cyclococcolithina macintyrei and the last occurrence of Helicopontosphaera parallela; the top by the last occurrence of Sphenolithus heteromorphus. This zone is recognized in Site 200, Core 9, Sections 1 to 6. 
TABLE 2

Comparison of Leg 20 Nannofossil Zonation with Martini's Standard Nannofossil Zones

\begin{tabular}{|c|c|c|c|}
\hline $\begin{array}{l}\text { Zones of Martini } \\
\text { (1971) }\end{array}$ & $\begin{array}{l}\text { Leg } 20 \text { Zonation Following Bukry } \\
\text { (1973) and Thierstein (1971) }\end{array}$ & $\begin{array}{l}\text { Oceanic Nannofossil } \\
\text { Stages }\end{array}$ & Periods \\
\hline NN21 & E. huxleyi & \multirow{4}{*}{ Pintan } & Holocene \\
\hline NN20 & G. caribbeanica & & \multirow{3}{*}{ Pleistocene } \\
\hline \multirow{2}{*}{ NN19 } & G. caribbeanica & & \\
\hline & E. annula & & \\
\hline NN17 & D. pentaradiatus & \multirow{2}{*}{ Marchenan } & \multirow{2}{*}{ Late Pliocene } \\
\hline NN16 & D. tamalis & & \\
\hline \multirow{2}{*}{ NN15 } & D. asymmetricus & \multirow{4}{*}{ Genovesan } & \multirow{4}{*}{ Early Pliocene } \\
\hline & S. neoabies & & \\
\hline NN14 & C. rugosus & & \\
\hline $\mathrm{NN} 13$ & $\begin{array}{l}\text { C. amplificus } \\
\text { T. rugosus }\end{array}$ & & \\
\hline \multirow{2}{*}{ NN10 } & D. neorectus & \multirow{2}{*}{ Sorolian } & \multirow{2}{*}{ Late Miocene } \\
\hline & D. bellus & & \\
\hline NN8 & C. coalitus & \multirow{3}{*}{ Faisian } & \multirow{3}{*}{ Middle Miocene } \\
\hline NN7 & D. kugleri & & \\
\hline NN5 & S. heteromorphus & & \\
\hline NN4 & H. ampliaperta & Aruban & Early Miocene \\
\hline NP16 & D. saipanensis & Palmyran & Middle Eocene \\
\hline NP13 & D. lodoensis & Campechean & Early Eocene \\
\hline \multirow{2}{*}{ NP9 } & C. eodela & \multirow{2}{*}{ Cantabrian } & \multirow{2}{*}{ Late Paleocene } \\
\hline & C. bidens & & \\
\hline NP2-4 & C. tenuis & Shatskyan & Early Paleocene \\
\hline & $\begin{array}{l}\text { M. mura } \\
\text { L. quadratus }\end{array}$ & \multirow{3}{*}{ Bermudan } & $\begin{array}{l}\text { Late } \\
\text { Maastrichtian }\end{array}$ \\
\hline & T. trifidus & & $\begin{array}{l}\text { E. Maastrichtian } \\
\text { L. Campanian }\end{array}$ \\
\hline & $\begin{array}{l}\text { A. bollii } \\
\text { C. crenulatus }\end{array}$ & & $\begin{array}{l}\text { E. Hauterivian } \\
\text { Valanginian }\end{array}$ \\
\hline
\end{tabular}

\section{Helicopontosphaera ampliaperta Zone}

In the absence of the typical species, this zone is recognized here as the interval from the first occurrence of Sphenolithus heteromorphus (base) to the first occurrence of Cyclococcolithina macintyrei (top). This zone is recognized in Site 200, Core 10, core catcher.

\section{Discoaster saipanensis Subzone}

This subzone is characterized by the occurrence of Dictyococcites bisectus together with Chiasmolithus grandis and is found in Site 202, Core 2, core catcher.

\section{Discoaster lodoensis Zone?}

In Site 200, Core 2A, core catcher, a poor assemblage with rare atypical Discoaster sp. aff. D. lodoensis and $D$. barbadiensis could not be dated more accurately than early Eocene, but may be close to the Discoaster lodoensis Zone.

\section{Campylosphaera eodela Subzone}

The interval between the last Chiasmolithus bidens (base) and the last Discoaster multiradiatus (top) is represented from Site 199, Core 8, core catcher, to Site 199, Core 7 , Section 1 .

\section{Chiasmolithus bidens Subzone}

The interval between the first Discoaster multiradiatus (base) and the last Chiasmolithus bidens (top) is represented from Site 199, Core 9, Section 1, to Site 199, Core 10 , Section $2(40 \mathrm{~cm})$.

\section{Cruciplacolithus tenuis Zone}

This zone is characterized by the first occurrence of Cruciplacolithus tenuis without any species typical of the Fasciculithus tympaniformis Zone. Coccolithus cavus and Thoracosphaera sp. are typical forms. Massive occurrence of presumably mostly reworked Cretaceous forms is typical. This zone is found from Site 199, Core 10, Section 2 (50 $\mathrm{cm})$, to Site 199, Core 11, Section $1(91 \mathrm{~cm})$.

\section{Micula mura-Lithraphidites quadratus "Zonal-interval"}

The base of this interval is the last occurrence of Broinsonia parca and Tetralithus trifidus; the top is characterized by the first Coccolithus cavus and Cruciplacolithus tenuis. A characteristic fossil for this interval is Arkhangelskiella cymbiformis. Only few specimens of Micula mura are found in situ; more of this species and 
Lithraphidites quadratus can be observed redeposited in the Paleocene. This interval is found in Site 199, Core 1, Section 2 and core catcher.

\section{Tetralithus trifidus Zone}

This zone is characterized by the typical species and is represented in Site 199, Core 12, Section 1 and core catcher. The occurrence of large forms of Arkhangelskiella cymbiformis in Site 199, Core 12, Section 1, may indicate a distinctive subzone.

\section{Cretarhabdus crenulatus-Microrhabdulus bolii "Zonal-interval"}

The combination of the first appearances of 'Cretarhabdus crenulatus' (sensu Thierstein, 1971) and Markalius circumradiatus and the last occurrence of Cruciellipsis cuvillieri would indicate that these sediments should be assigned to a part or all of the interval between the base of the Cretarhabdus crenulatus Zone to the lower part of the Microrhabdulus bollii Zone of Thierstein (1971). This interval is represented in Site 195, Cores 4 and 5; Site 195A drill bit at 383 meters; Site 195B, core catchers 1 to 3 ; Site 196 , core catchers 3 and 4.

TABLE 3

Nannofossil Species Considered in This Report

Apertapetra gronosa (Stover)

Arkhangelskiella cymbiformis Vekshina

Biantholithus sparsus Bramlette and Martini

Biscutum sulcato Worsley

Biscutum testudinarium Black

Biscutum blacki Gartner

Braarudosphaera sp.

Broinsonia parca (Stradner)

Catinaster coalitus Martini and Bramlette

? Ceratolithina vesca Bukry and Percival

Ceratolithus amplificus Bukry and Percival

Ceratolithus bizzarus Bukry

Ceratolithus cristatus Kamptner

Ceratolithus sp. aff. C. cristatus Kamptner

Ceratolithus primus Bukry and Percival

Ceratolithus rugosus Bukry and Bramlette

Ceratolithus tricorniculatus Gartner

Chiasmolithus bidens (Bramlette and Sullivan)

Chiasmolithus consuetus (Bramlette and Sullivan)

Chiasmolithus gigas (Bramlette and Sullivan)

Chiasmolithus grandis (Bramlette and Sullivan)

Chiasmolithus staurion (Bramlette and Sullivan)

Coccolithus cavus Hay and Mohler

Coccolithus sp. cf. C. crassus Bramlette and Sullivan

Coccolithus sp. cf. C. doronicoides Black and Barnes

Coccolithus miopelagicus Bukry

Coccolithus pelagicus (Wallich)

Crassapontosphaera jonesi Boudreaux and Hay

Cretarhabdus conicus Bramlette and Martini

'Cretarhabdus crenulatus' Bramlette and Martini (sensu Thierstein)

Cretarhabdus surirellus (Deflandre)

Cribrosphaerella ehrenbergii (Arkhangelsky)

Cribrosphaerella ehrenbergii (Arkhangelsky) teardrop-shaped form.

Cricolithus cyclus Worsley

Cruciellipsis cuvillieri (Manivit)

Cruciplacolithus tenuis (Stradner)

Cyclicargolithus floridanus (Roth and Hay)

Cyclagelosphaera margereli Noel

Cyclococcolithina leptopora (Murray and Blackman)

Cyclococcolithina lusitanica (Kamptner)

Cycloccolithina macintyrei (Bukry and Bramlette)
TABLE 3 - Continued

Cylindralithus crassus Stover

Diadorhombus rectus Worsley

Diazomatolithus lehmani Noel

Dictyococcites abisectus (Muller)

Dictyococcites bisectus (Hay, Mohler and Wade)

Dictyococcites scrippsae Bukry and Percival

Discoaster adamanteus Bramlette and Wilcoxon

Discoaster asymmetricus Gartner

Discoaster aulakos Gartner

Discoaster barbadiensis Tan

Discoaster bellus Bukry and Percival

Discoaster berggrenii Bukry

Discoaster bollii Martini and Bramlette

Discoaster brouweri Tan

Discoaster calcaris Gartner

Discoaster sp. cf. D. challengeri Bramlette and Riedel

Discoaster decorus (Bukry)

Discoaster deflandrei Bramlette and Riedel

Discoaster dilatus Hay

Discoaster druggii Bramlette and Wilcoxon

Discoaster exilis Martini and Bramlette

Discoaster extensus Hay

Discoaster hamatus Martini and Bramlette

Discoaster kugleri Martini and Bramlette

Discoaster sp. cf. D. lodoensis Bramlette and Riedel

Discoaster mohleri Bukry and Percival

Discoaster multiradiatus Bramlette and Riedel

Discoaster neohamatus Bukry and Bramlette

Discoaster neorectus Bukry

Discoaster nodifer Bramlette and Riedel

Discoaster ornatus Stradner

Discoaster pentaradiatus Tan

Discoaster perplexus Bramlette and Riedel

Discoaster saipanensis Bramlette and Riedel

Discoaster tamalis Kamptner

Discoaster quinqueramus Gartner

Discoaster pseudovariabilis Martini and Worsley

Discoaster prepentaradiatus Bukry and Percival

Discoaster surculus Martini and Bramlette

Discoaster variabilis Martini and Bramlette

Discolithina japonica Takayama

Discolithina segmenta Bukry and Percival

Eiffellithus turriseiffeli (Deflandre)

Emiliania annula (Cohan)

Emiliania huxleyi (Lohmann)

Emiliania ovata Bukry

Fasciculithus involutus Bramlette and Sullivan

Fasciculithus magnus Bukry and Percival

Fasciculithus sp. cf. F. mitreus Gartner

Fasciculithus tympaniformis Hay and Mohler

Gephyrocapsa caribbeanica Boudreaux and Hay

Gephyrocapsa oceanica Kamptner

Glaucolithus sp.

Helicopontosphaera granulata Bukry and Percival

Helicopontosphaera kamptneri Hay and Mohler

Helicopontosphaera parallela (Bramlette and Wilcoxon)

Helicopontosphaera sellii Bukry and Bramlette

Helicopontosphaera wallichii (Lohmann)

Heliolithus riedelii Bramlette and Sullivan

Heliorthus concinnus (Martini)

Lithastrinus sp. cf. L. moratus Stover

? Lithastrinus sp.

Lithraphidites carniolensis Deflandre

Lithraphidites quadratus Bramlette and Martini

Lophodolithus sp.

Manivitella pemmatoides (Deflandre)

Markalius circumradiatus (Stover)

Microrhabdulus decoratus Deflandre

Microrhabdulus stradneri Bramlette and Martini

Micula decussata Vekshina

Micula mura (Martini)

Oolithotus antillarum (Cohen) 
TABLE 3 - Continued

Parhabdolithus embergeri Noel

Parhabdolithus splendens Deflandre

Podorhabdus dietzmannii (Reinhardt)

Pontosphaera discopora Schiller

Prediscosphaera cretacea (Arkhangelsky)

Rhabdosphaera clavigera (Murray and Blackman)

Reticulofenestra hillae Bukry and Percival

Reticulofenestra pseudoumbilica (Gartner)

Reticulofenestra umbilica (Levin)

Rucinolithus radiatus Worsley

Scapholithus fossilis Deflandre

Scyphosphaera globulata Bukry and Percival

Scyphosphaera pulcherrima Deflandre

Scyphosphaera div. sp.

Sphenolithus abies Deflandre

Sphenolithus anarrhopus Bukry and Bramlette

Sphenolithus belemnos Bramlette and Wilcoxon

Sphenolithus heteromorphus Deflandre

Sphenolithus moriformis (Brönnimann and Stradner)

Sphenolithus neoabies Bukry and Bramlette

Sphenolithus predistentus Bramlette and Wilcoxon

Sphenolithus radians Deflandre

Sphenoradiatus sp.

Stephanolithion laffittei Noel

Syracosphaera sp. cf. S. pulchra Lohmann

Tetralithus aculeus (Stradner)

Tetralithus gothicus Deflandre

Tetralithus obscurus Deflandre

Tetralithus trifidus (Stradner)

Tetralithus variabilis Worsley

Thoracosphaera sp.

Toweius craticulus Hay and Mohler

Toweius eminens (Bramlette and Sullivan)

Tranolithus sp.

Triradiate forms, mostly Discoaster surculus

Triquetrorhabdulus carinatus Martini

Umbilicosphaera mirabilis Lohmann

Watznaueria barnesae (Black)

Watznaueria britannica (Stradner)

Watznaueria deflandrei (Manivit)

Watznaueria jurapelagicus Worsley

Zygodiscus sigmoides Bramlette and Sullivan

\section{SITE DISCUSSIONS}

\section{Sites 195 and 196}

(195: lat. $32^{\circ} 46.40^{\prime} \mathrm{N}$., long. $146^{\circ} 59.73^{\prime} \mathrm{E}$., depth $5968 \mathrm{~m}$ ) (196: lat. $30^{\circ} 06.97^{\prime} \mathrm{N}$., long. $148^{\circ} 34.49^{\prime} \mathrm{E}$., depth $6194 \mathrm{~m}$ )

Only the lower part of these holes, consisting of a chalk-chert sequence, shows nannofossils of early Hauterivian to Valanginian age. The distribution of species is shown in Figure 2. The combination of data from the cores of Holes 195, 195 A, and 195B covers a section, 114 meters in thickness, of nannofossil-bearing sediments of this age. Little sediment was recovered, however, and some samples consist of scraps of sediment adhering to the drill bit or center bit only. No biostratigraphic differentiation could be recognized in the eight samples examined. The assemblages are comparatively poor, showing fair to strong overcalcification. With increasing calcification a trend towards predominance of Watznaueria barnesae is observed.

The age interpretation is based on Thierstein (1971), who established nannofossil zones in the early Cretaceous of southwest France. Although this zonation is based on a combination of several parallel profiles in this area, further work on assemblages of similar age in other regions could slightly modify these conclusions. Three species, 'Cretarhabdus crenulatus' (sensu Thierstein), Markalius circumradiatus, and Cruciellipsis cuvillieri, which occur throughout our sequence, have ranges restricting the age of the assemblage from early Hauterivian to Valanginian. 'Cretarhabdus crenulatus' (sensu Thierstein) ranges from late Berriasian to Late Cretaceous, Markalius circumradiatus has a range from Valanginian to Late Cretaceous, and Cruciellipsis cuvillieri ranges from Berriasian to the early Hauterivian (Thierstein, 1971). The lack of the genera Nannoconus, Braarudosphaera, and Micrantholithus, which are important constituents of the nannoflora in many sediments of similar age, could indicate deep-water deposition (selective dissolution or primary facies restriction of these genera).

If a duration of 12 to 15 m.y. is accepted for this time interval, the resulting minimum sedimentation rate would be 8 to $10 \mathrm{~m} / \mathrm{m} . \mathrm{y}$.

\section{Site 199}

(lat. $13^{\circ} 30.78^{\prime} \mathrm{N}$., long. $156^{\circ} 10.34^{\prime} \mathrm{E}$., depth $6100 \mathrm{~m}$ )

The distribution of species is shown in Figure 3. The upper part of this hole (Cores 1 to 6) consists of a turbidite section of Pliocene to middle Miocene age. The lower part (Cores 7 to 12) is a chalk-chert section of late Paleocene to late Campanian age.

Calcareous nannofossils are found in all cores except Core 13, which is carbonate free. The preservation of the nannofossils varies. Etching and strongly differentiated preservation is typical for Cores 1 to 6 ; overcalcification is found in the lower part of the hole.

Cores 1 to 6 show reworked nannofossils of Eocene, Oligocene, and early Miocene age and are interpreted to be of turbidite origin. The possibility of overrepresentation of a reworked interval and no recognized synchronous fossils prevents a precise age determination. Therefore, the youngest represented time interval is stated, with the reservation that this interpretation could also be due to derived fossils. The overrepresentation of certain nannofossil zones in samples, which show younger foraminiferal dates, suggests an incomplete mixing of some sediments in the form of semiconsolidated chips within the approximate size range of the nannofossil samples ( 1 to 3 cubic $\mathrm{mm}$ ). In Core 6 , for example, Oligocene species are predominant in one nannofossil preparation, while the foraminiferal sample, using about 10 cubic $\mathrm{cm}$ of sediment, shows a mixture of different ages with middle Miocene species as the youngest elements. Reworked fossils derived from gradual erosional processes are expected to have a more consistent appearance within a series of samples than material of turbidite origin.

In the second major lithological unit, the chalk-chert section of Cores 7 to 12 , the main features are an unusually high sedimentation rate in the late Paleocene Discoaster multiradiatus Zone and reworking conditions which are significant enough to affect the calculations of the sedimentation rate.

Core $1(57.5$ to $67 \mathrm{~m})$-The youngest age represented is the early Pliocene Discoaster asymmetricus Zone, with the typical species and abundant Sphenolithus abies. Reworked 


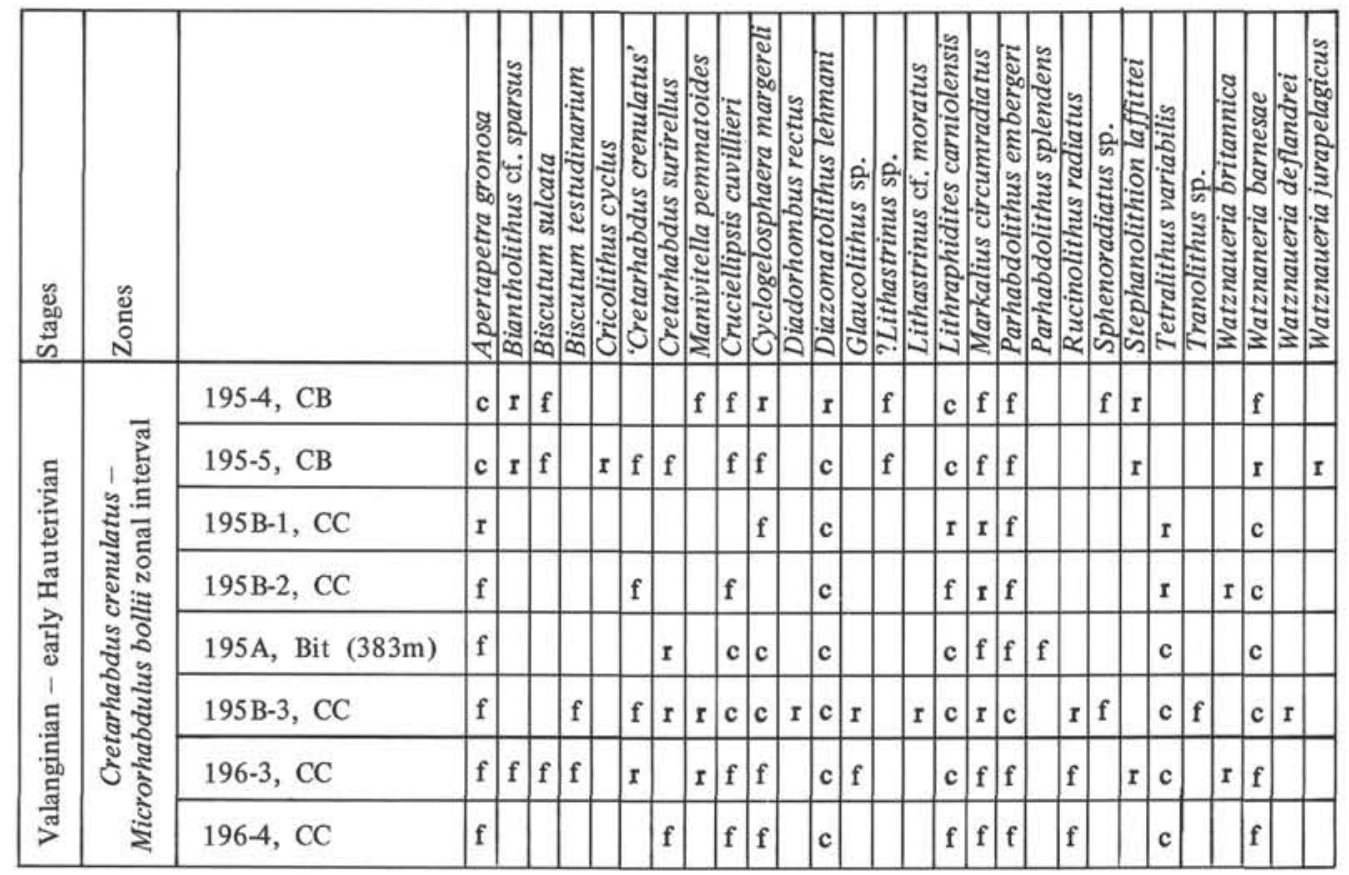

Figure 2. DSDP-20-195, 196 species distribution: $\mathrm{r}=$ rare $; \mathrm{f}=$ few; $\mathrm{c}=$ common $; \mathrm{a}=$ abundant.

nannofossils of Eocene to Oligocene age (Dictyococcites scrippsae, Reticulofenestra umbilica), and of late Miocene age (Discoaster quinqueramus, $D$. berggreni) are present in large numbers.

Core 2 (67 to $76.5 \mathrm{~m})$-The Catinaster coalitus Zone from the middle Miocene is represented by the typical species. No younger elements have been observed. Cyclicargolithus floridanus and Discoaster deflandrei represent derived early Miocene. Dictyococcites bisectus represents reworked Eocene or Oligocene.

Cores 3 and $4(76.5$ to $86 \mathrm{~m})(86$ to $95.5 \mathrm{~m})-$ The youngest elements are Cyclococcolithina leptopora and Discoaster variabilis (Core 3 ) and D. kugleri and D. exilis (Core 4) from the middle Miocene. The following reworked forms are found: Dictyococcites bisectus, D. scrippsae, Reticulofenestra umbilica (Eocene or Oligocene); $D$. abisectus (Oligocene or early Miocene); Sphenolithus belemnos (early Miocene).

Core 5 (143 to $152.5 \mathrm{~m})-$ Out of five samples examined, four were barren and the remaining one contains a few specimens from the Sphenolithus heteromorphus zone. These are obviously reworked because of the younger age indication in Core 6.

Core 6 (200 to $209.5 \mathrm{~m}$ )-This core has predominantly Eocene-Oligocene species: Ceratolithina? vesca, Discoaster barbadiensis, Dictyococcites bisectus, Chiasmolithus grandis, Sphenolithus predistentus. Only the rare occurrence of questionable Discoaster bollii could indicate middle Miocene.

Core $7(185.5$ to $195 \mathrm{~m}), 8(195$ to $304 \mathrm{~m})$ and 9 (304 to $314 \mathrm{~m}$ )-Here a well-preserved and rich assemblage from the late Paleocene Discoaster multiradiatus Zone is found with Fasciculithus involutus. Below Core 8 the occurrence of Chiasmolithus bidens may indicate the lower part of the Discoaster multiradiatus Zone, the Chiasmolithus bidens
Subzone. Cores 7 and 8 may represent the Campylosphaera eodela Subzone (negative evidence). Specimens of Fasciculithus sp. aff. $F$. mitreus show considerable variation in ornamentation and projections due to overcalcification. The proportion of reworked Cretaceous fossils was estimated as between 5 and 35 percent in this part of the section. Discoaster mohleri occurs fairly frequently, and some specimens of Heliolithus riedeli are apparent, indicating also reworked early Paleocene. The percentage of early Paleocene fossils is, however, difficult to estimate because of many forms ranging into the Discoaster multiradiatus Zone.

Core 10 (371 to $380 \mathrm{~m})$-Section 1 and Section 2 down to $40 \mathrm{~cm}$ still contain nannofossils of the Discoaster multiradiatus Zone. With a change in lithology, a major time break can be observed. Section 2 below $60 \mathrm{~cm}$ contains a majority of reworked late Cretaceous fossils; however, it also contains the Danian or earliest Paleocene forms Gruciplacolithus tenuis and Coccolithus cavus. The reddish stained, cross-laminated chalk between 40 and 60 $\mathrm{cm}$ represents sedimentation over $5 \mathrm{~m}$.y. and contains a late Cretaceous assemblage without any Paleocene elements. It obviously consists entirely of reworked sediments.

Core 11 (399.5 to $409 \mathrm{~m}$ )-Section 1 at $93 \mathrm{~cm}$ still contains the Danian-Paleocene forms Coccolithus cavus and Cruciplacolithus tenuis. In Section 2, $68 \mathrm{~cm}$, and in the core catcher sample, however, a pure Maastrichtian assemblage is found, with Arkhangelskiella cymbiformis, Micula decussata, Cylindralithus gallicus, and few M. mura, the last species indicating the Micula muca Zone of the late Maastrichtian.

Core 12 (437.5 to $447 \mathrm{~m})$-The coccoliths recovered from the core catcher sample show the Tetralithus trifidus Zone with the typical species and Broinsoina parca, representing the late Campanian to earliest Maastrichtian 
H. HEKEL

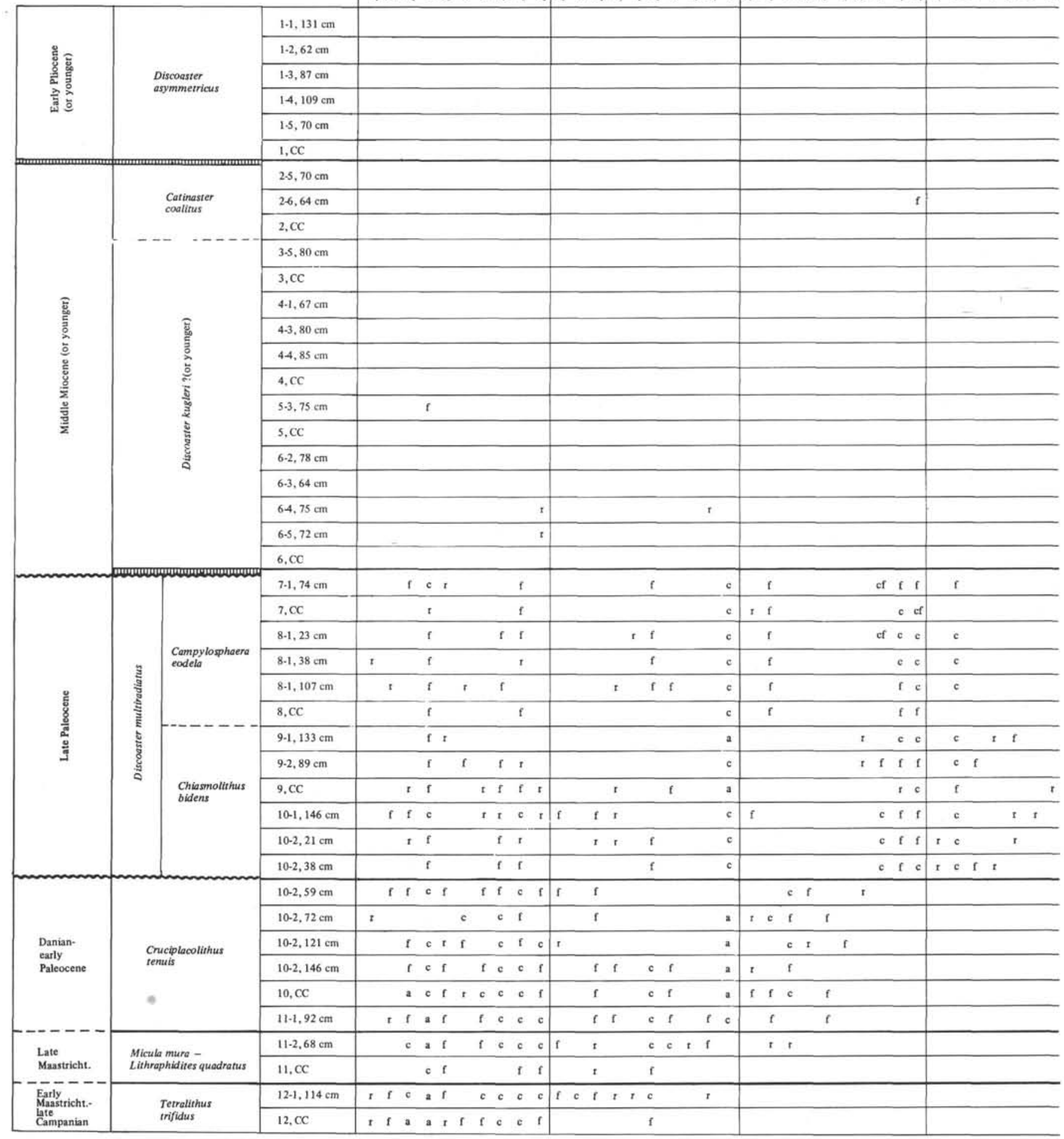

Figure 3. DSDP-20-199 species distribution: $\mathrm{r}=$ rare; $\mathrm{f}=$ few $; \mathrm{c}=$ common; $\mathrm{a}=$ abundant . 


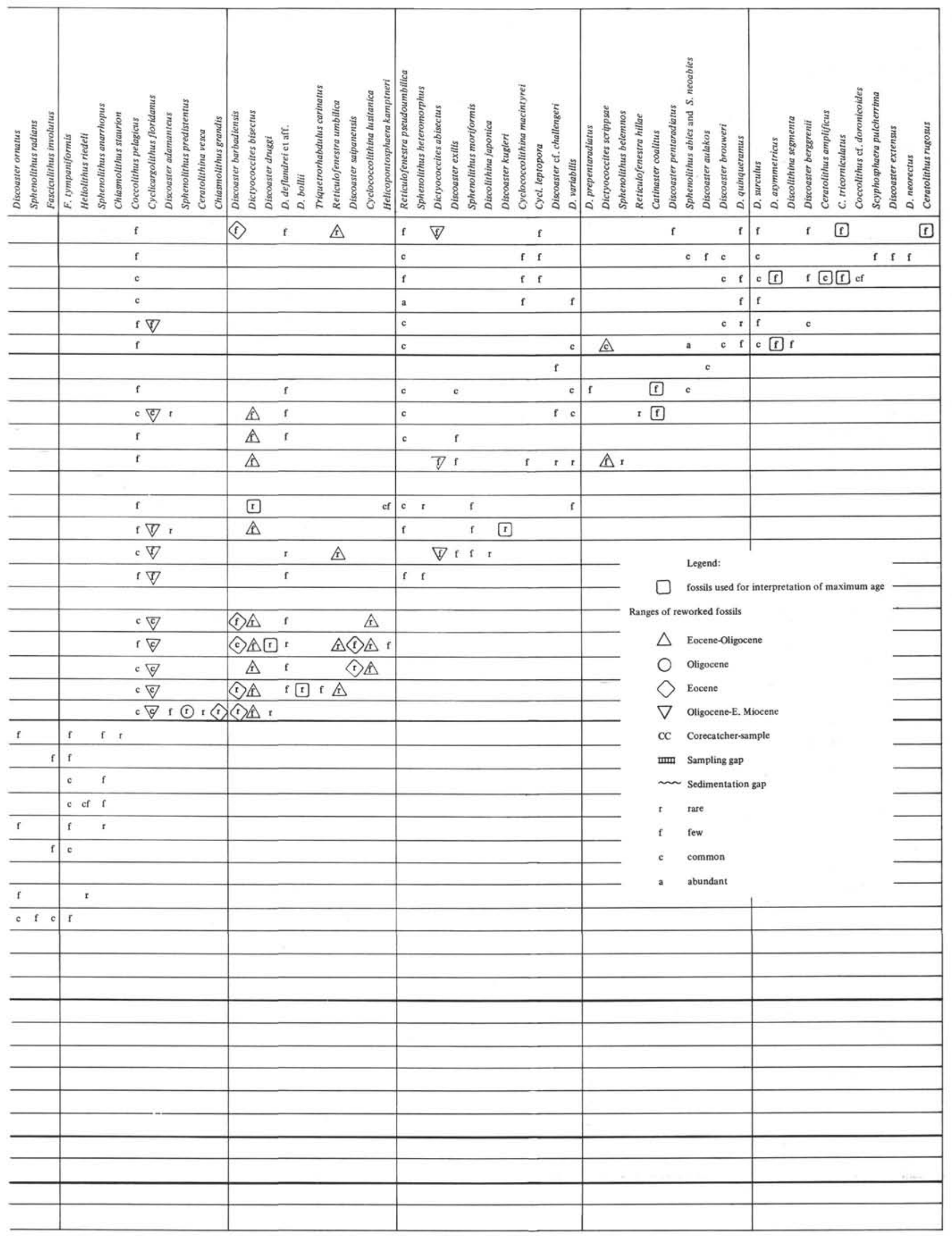

Figure 3. (Continued). 
interval. The sample from Section 1 at $115 \mathrm{~cm}$ may represent a higher part of this zone, as indicated by the appearance of large forms of Arkhangelskiella cymbiformis.

\section{Sedimentation Rates and Reworking}

Turbidite section-Taking the interval between the Discoaster asymmetricus Zone and the Discoaster kugleri Zone as about 10 m.y., a sedimentation rate of $15 \mathrm{~m} / \mathrm{m} . y$. is evident. Accepting similar conditions down to the next seismic reflector (approximately at Core 7), the deposition of the remaining 80 meters required not more than 5 m.y. The deposition of the turbidite, therefore, probably began within the early Miocene, and a sedimentation gap or very condensed sedimentation between Miocene and late Paleocene is likely, although deposits of Eocene and Oligocene age must exist in the source area of the turbidites because they contain many reworked species typical of these periods. The reduced representation of the synchronous component of the nannofossil assemblage may reflect better conditions for biogenic carbonate sedimentation during Eocene-Oligocene time than in the Mio-Pliocene. This could be due to changes in productivity or to subsidence of the source area towards the carbonate compensation depth.

Chalk-chert section-The main features are an unusually high sedimentation rate for this type of deposit during the late Paleocene $(40 \mathrm{~m} / \mathrm{m} . \mathrm{y}$. uncorrected $)$ and a much smaller figure for the Campanian-Maastrichtian ( $3 \mathrm{~m} / \mathrm{m} . \mathrm{y}$.).

Areas of high sedimentation rates are commonly correlated with areas of high productivity in open-sea conditions, where nannofossils and foraminiferal tests are the predominant constituents of the sediments. In the early and late Paleocene in this hole, reworked Cret aceous fossils are common to predominant. A correction of the total sedimentation rate, considering the reworked percentage, seems to be necessary to evaluate the amount of sediment due to the oceanic productivity during the sedimentation time. Quantitative evaluation of reworked Cretaceous material is possible because there is a major change in nannofossil assemblages between Cretaceous and Paleocene (Bramlette and Martini, 1964).

The question of a brief transitional interval in the latest Cretaceous or earliest Paleocene was discussed by Bukry et al. (1971), who observed substantial proportions of Cretaceous fossils in the earliest part of the Paleocene of DSDP Site 47 on the Shatsky Plateau. They interpreted this as a short time interval, characterized by gradual disappearance of Cretaceous forms and gradual appearance of Paleocene forms within the lower part of the Cruciplacolithus tenuis Zone-interval. Observations on some Maastrichtian-Danian localities could support their theory, although these occurrences are mostly interpreted as being reworked (PerchNielsen, 1969, Tab. 1). In the case of the Cruciplacolithus tenuis Zone at Site 199, there are arguments for a considerable amount of undoubted reworking. Firstly, species which are restricted to a range below the top of the Maastrichtian, such as Broinsonia parca and Tetralithus trifidus are found in this zone. Secondly, in the cross-laminated tuffaceous chalk, which represents the 20 $\mathrm{cm}$ of sediment between the Cruciplacolithus tenuis Zone and the Discoaster multiradiatus Zone in Core 10, Section 2, a pure assemblage of Cretaceous nannofossils has been found. Thirdly, a considerable amount of Cretaceous fossils can be found in the late Plaeocene, where these forms are obviously reworked, as no Cretaceous forms persist into known sections of this age.

For the correction of the sedimentation rate, the total amount of Cretaceous coccoliths is interpreted as being reworked. The appearance of Heliolithus riedeli and Discoaster mohleri, the latter species in considerable numbers, indicates reworking of some of the missing zones into the $D$. multiradiatus Zone. This shows that the sedimentation gap between the $D$. multiradiatus Zone and the Cruciplacolithus tenuis Zone is of local nature at Site 199. In the source area of the reworking, a more complete Paleocene section is to be expected. The amount of reworking cannot be evaluated quantitatively, because the majority of early Paleocene forms range into the $D$. multiradiatus Zone.

The sedimentation rates of the chalk-chert section are shown in Figure 4. Accepting a Campanian-Maastrichtian duration of 12 m.y., 35 meters of sedimentation would give a rate of about $3 \mathrm{~m} / \mathrm{m} . \mathrm{y} . ;$ and 30 meters of Cruciplacolithus tenuis Zone with a duration of about $3 \mathrm{~m} . \mathrm{y}$., would give an uncorrected sedimentation rate of $10 \mathrm{~m} / \mathrm{m} . \mathrm{y}$. Interpreting the Cretaceous fossils in this section as being predominantly reworked, the synchronous component of the biogenic sedimentation is only about 20 percent of the whole. The resulting corrected sedimentation rate would than be 2 $\mathrm{m} / \mathrm{m} . \mathrm{y}$. In the sample from the Interval 50 to $51 \mathrm{~cm}$ in Section 2 of Core 10, only reworked Cretaceous fossils were found. In the fine laminated tuffaceous chalk layer from 40 to $60 \mathrm{~cm}$ in this core, the time interval from the Fasciculithus tympaniformis Zone to the Discoaster mohleri Zone (about 5 m.y.) has to be condensed The late Paleocene $D$. multiradiatus Zone is estimated to last about 2 m.y. The thickness for this zone is 80 meters, giving an uncorrected sedimentation rate of $40 \mathrm{~m} / \mathrm{m} . \mathrm{y}$. The correction would be about 20 percent, following the observation of 3 to 35 percent Cretaceous fossils. The amount of Paleocene fossils, reworked into the Discoaster multiradiatus Zone, is not possible to estimate as has been remarked above. The only approximation which could be made is based on the fact that the earlier Paleocene and the represented Cretaceous interval are about equally long and may have similar sedimentation rates in the source area of the reworked sediments. Therefore, a factor twice as high as the amount of Cretaceous reworking could limit the order of magnitude of dilution by foreign sediment. The rate of synchronous, autochthonous sedimentation is therefore considered as within 24 to $32 \mathrm{~m} / \mathrm{m} . \mathrm{y}$.

\section{Sites 200 and 202}

(200: lat. $12^{\circ} 50.20^{\prime} \mathrm{N}$., long. $156^{\circ} 46.96^{\prime} \mathrm{E}$., depth $1564 \mathrm{~m}$ ) (202: lat. $12^{\circ} 48.90^{\prime} \mathrm{N}$., long. $156^{\circ} 57.15^{\prime} \mathrm{E}$., depth $1515 \mathrm{~m}$ )

In these sites the sediment cover of the Ita Mai Tai Seamount was sampled. In 114 meters of sediment an early Miocene to Pleistocene section has been drilled at Site 200, at 1479 meters depth. Nannofossil distribution is shown in Figure 5. In Hole 200A, core catcher 2, an Eocene age is recorded at 132 meters. At Site 202 some elements of the middle Eocene Discoaster saipanensis Subzone have been 


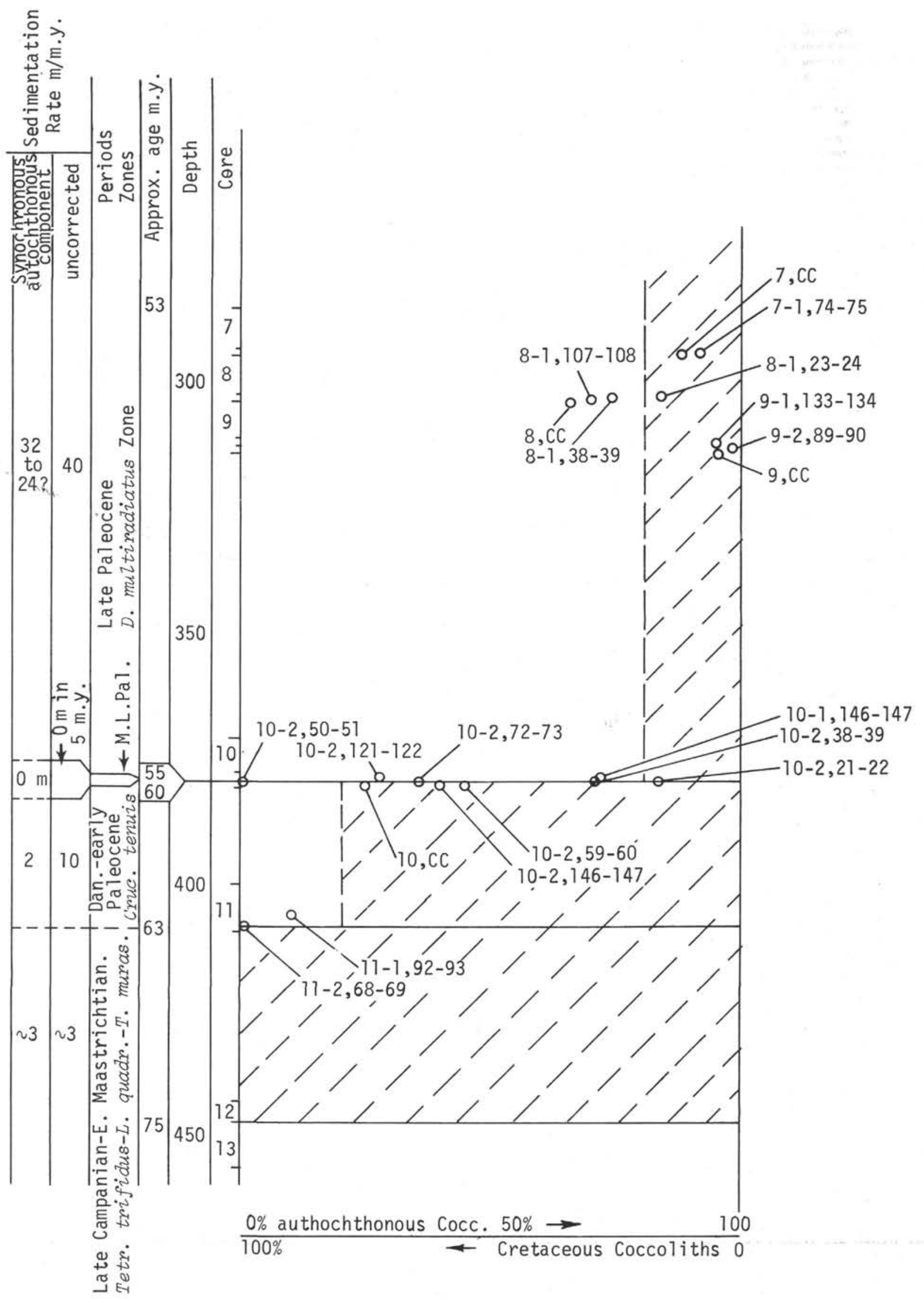

Figure 4. Cretaceous fossils in chalk-chert section of Hole 199. 


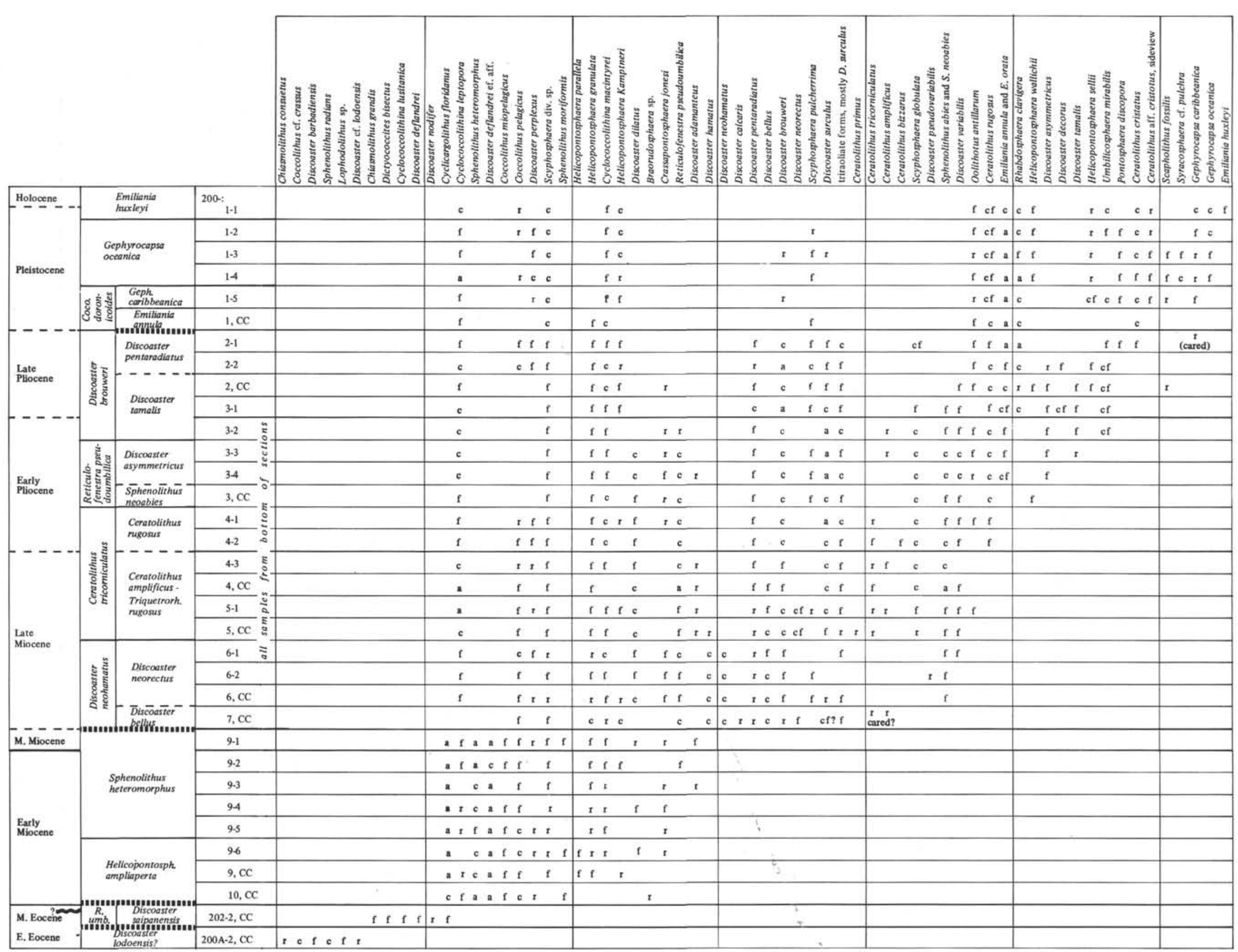

Figure 5. DSDP-20-200, 200A, 202, species distribution: $\mathrm{r}=$ rare $; \mathrm{f}=$ few; $\mathrm{c}=$ common; $\mathrm{a}=$ abundant . 
recovered from a more marginal area of the seamount. Between the middle Eocene and the early Miocene sections there is evidence for a sedimentation gap or markedly condensed sedimentation.

represented (probably not recovered). In Sections 1 and 2, the Discoaster pentaradiatus Subzone is found with signs of uphole contamination in Section 1. The core catcher sample still contains Discoaster tamalis, indicating the $D$. tamalis Subzone. Triradiate forms found in this and all deeper cores show in some cases such a close resemblance to Tribrachiatus orthostylus from the Eocene that reworking of this fossil has been considered. But the fact that no other typical Eocene nannofossils are present is contrary to this suggestion. Also the occurrence of these forms only up to the uppermost limit of the range of the Pliocene discoasters strongly indicates that these specimens are triradiate forms of Discoaster surculus, D. dilatus, and $D$. brouweri, which have been subjected to recrystallization, overshadowing the specific features.

Hole 200, Core 3 (19 to $28.5 \mathrm{~m}$ )-In Sections 1 and 2 the Discoaster tamalis Subzone is still represented. Sections 3 and 4 are assigned to the D. asymmetricus Subzone and the core catcher sample represents the Sphenolithus neoabies Subzone. Here discoasters predominate over coccoliths in some samples, possibly indicating winnowing of the finer grain sizes. The absence of Coccolithus pelagicus in this core may indicate deposition in a warmer environment. In Sections 3 and 4 , specimens of the six-rayed form $D$. formosus are present. They possess thick central knobs (Plate 2, Figures 5-7). Specimens of Scyphosphaera, especially $S$. globulata, are common. Some specimens of the late Miocene to Pliocene discoasters seem to be prone to disintegration and their rays are found frequently as elongated carbonate spicules.

Hole 200 , Core 4 (28.5 to $38 \mathrm{~m})$-Sections 1 and 2 are assigned to the Ceratolithus rugosus Subzone, as they include the overlap of the ranges of Ceratolithus rugosus and Ceratolithus tricorniculatus. Sections 3 and 4 could only be assigned to the interval between Triquetrorhabdulus rugosus Subzone and Ceratolithus amplificus Subzone, as Triquetrorhabdulus rugosus was not found consistently in our preparations. Some specimens of Ceratolithus bizzarus are present in this interval.

Hole 200 , Core 5 (38 to $47.5 \mathrm{~m}$ )-Section 1 and the core catcher sample are assigned to the interval between the Triquetrorhabdulus rugosus and Ceratolithus amplificus subzones because of the occurrence of $C$. tricorniculatus. The Discoaster quinqueramus Zone seems to be lost in a sampling gap.

Hole 200, Core $6(47.5$ to $57 \mathrm{~m})$-Sections 1 and 2 and the core catcher sample are assigned to the Discoaster neorectus Subzone of the $D$. neohamatus Zone, mainly because of the first common occurrence of $D$. brouweri and the absence of $D$. quinqueramus. $D$. hamatus and $D$. neohamatus are common components of this assemblage. Carbonate bodies, looking like overcalcified specimens of Ceratolithus primus, differing from this species however, by a bright birefringence color in polarized light, occur in Cores 5 and 6 . This morphology is typical for spicules of certain forms of ascidians. Their presence may be a shallow-water indicator.
Hole 200, Core 7 (5.7 to $66.5 \mathrm{~m}$ )-Only a core catcher sample was recovered, showing signs of uphole contamination. The main difference from Core 6 is that Discoaster brouweri is only represented as rare specimens. D. bellus

Hole 200 , Core 1 ( 0 to $9.5 \mathrm{~m}$ )-Here, a good recovery of five sections seems to represent most of the Pleistocene. In Section 1, presence of the Emiliania huxleyi Zone is established by examination with the electron microscope. Sections 2 to 4 have only been studied with the light microscope and represent the Gephyrocapsa oceanica Zone. Section 5 represents the $G$. caribbeanica Zone, and in the core catcher sample the Emiliania annula Zone has been found.

The nannofossils are only slightly recrystallized; the genus Ceratolithus may be more affected by calcite overgrowth. Cyclococcolithina sp. aff. C. macintyrei is persistent throughout this core. In Sections 1, 2, and 4, few specimens of Coccolithus pelagicus are present, possibly indicating colder periods. Contamination with prePleistocene material is unlikely because no discoasters have been found. Several side-views of Ceratolithus sp. aff. $C$. cristatus, some with fine teeth, resembling Triquetrorhabdulus rugosus, are represented. Ceratolithus rugosus and C. cristatus occur in two size ranges (possible dimorphism ?).

Hole 200, Core $2(9.5$ to $19 \mathrm{~m})$-The Cyclococcolithina macintyrei Subzone of the Discoaster brouweri Zone is not and $D$. neohamatus are important components. Helicopontosphaera kamptneri is unusually common in this sample.

Hole 200, Core 8 (66.5 to $76 \mathrm{~m})$-Only a core catcher sample was recovered and no interpretation is made because of predominance of caved material.

Hole 200 , Core 9 (85.5 to 95 )-Good sediment recovery (6 sections) was had. Discoasters, especially from the $D$. deflandrei group, are common, but show a high degree of recrystallization. $D$. perplexus occurs nevertheless in thin, well-preserved specimens, indicating different recrystallization properties, rather similar to those of the coccoliths, which are generally well preserved in these samples. Specimens of Scyphosphaera show a thin to rather etched appearance. D. exilis, which should be typical of the Sphenolithus heteromorphus Zone, cannot be identified, probably because of the massive recrystallization. The disappearance of Helicoponthosphaera parallella and the first occurrence of a number of specimens of Cyclococcolithina macintyrei is used to differentiate the $S$. heteromorphus Zone (Sections 1 to 5) from the $H$. ampliaperta Zone below (Sections 6 and core catcher); H. ampliaperta itself could not be found. All samples are rich in welldeveloped $S$. heteromorphus, with specimens showing a size range from 4 to $20 \mu$. Forms with extremely long apical spines may indicate dimorphism. Commonly occurring carbonate particles of elongated shape seem to be isolated apical spines of this form. The genus Scyphosphaera is well represented with large specimens and shows some distinctly different froms from those in the upper part of the section.

Hole 200, Core 10 (104.5 to 114.0)-Only the core catcher sample is available, indicating the Helicopontosphaera ampliaperta Zone with massive occurrence of Spenolithus heteromorphus. Rare specimens of Braarudosphaera are present. 
Hole $200 \mathrm{~A}$, Core $1(65.5$ to $75 \mathrm{~m})$-The nannofossil association with Ceratolithus rugosus must be caved, as in a similar depth $(75 \mathrm{~m})$, early Miocene is already represented in Hole 200.

Hole $200 \mathrm{~A}$, Core $2(122.5$ to $132 \mathrm{~m})-$ Only a few nannofossils were recovered from the well-sorted globigerina sands. Uphole contamination cannot be excluded due to the nature of the sediment. The discoasters seem to be less recrystallized and contrast sharply with those which are caved from the Miocene part of the section. Only a rather broad age-interpretation (early to middle Eocene) is given, because of the lack of the typical discoasters, which would be expected in the Eocene. The rather long-ranging coccoliths include Lophadolithus, Chiasmolithus grandis, Chiasmolithus consuetus, Cyclococcolithina formosa and Coccolithus cf. crassus. The discoasters include $D$. cf. barbadiensis and atypical $D$. cf. lodoensis in small numbers.

Hole 202, Core 1 (49 to $58.5 \mathrm{~m}$ )-The age determination of early Pliocene (Discoaster asymmetricus Subzone) would conform with wedging out of the sediments close to the edge of Ita Mai Tai Seamount. The association of nannofossils is rich and similar to Hole 200, Core 3. Isolated late Miocene species (D. neohamatus, D. quinqueramus) are interpreted as being reworked.

Hole 202, Core 2 (65 to $74 \mathrm{~m}$ )-As in Hole 200A, Core 2 , only a few nannofossils were recovered from the globigerina sands of this sample. Nevertheless the Discoaster saipanensis Subzone of the Reticulofenestra umbilica Zone was found, as indicated by the occurrence of Dictyococcites bisectus and Chiasmolithus grandis. Further species are Discoaster nodifer, Cyclococcolithina lusitanica, and Cyclicargolithus floridanus.

\section{Sedimentation Rates}

See Figure 6 for sedimentation rates based on nannofossil dates. The ages estimated for the nannofossil zone boundaries are taken from Bukry (1973). The recovered parts of the cores are shifted upwards in the cored interval, as a standard procedure. Thus certain sedimentation rates may be affected slightly. Parts of the section with information gaps are averaged. The sedimentation on the seamount is affected by the balance of biogenic productivity and sweeping off of the sediment by current systems. Peaks in the sedimentation rate occur in the early Miocene, in the late Miocene, and between early and late Pliocene. The high rate estimated between Core 6 and Core 7 may be unreliable, because of the possibility of caving, as the core catcher sample is the only recovery of Core 7.

\section{ACKNOWLEDGMENTS}

Special thanks are extended to D. Bukry, U. S. Geological Survey, La Jolla; A. R. Edwards, Geological Survey of New Zealand, Lower Hutt; A. MacIntyre, Lamont-Doherty Geological Observatory, New York, and T.R. Worsley, University of Washington, Seattle, for valuable discussions and information during the preparation of the report. R. Greber (plant-pathology section of the Department of Primary Industries, Brisbane) made the departmental electron microscope available for this study, and much help in the electron microscopy has been obtained from D. Gowanlock of the same department.

Valuable suggestions were made by J.T. Woods, Chief Government Geologist, and N. J. de Jersey, Palynology Section, Geological Survey of Queensland.

Participation in Leg 20 was made possible by special leave of absence granted by the Public Service Board of Queensland.

\section{REFERENCES}

Bramlette, M. N. and Martini, E., 1964. The great change in calcareous nannoplankton fossils between the Maastrichtian and Danien: Micropaleontology, v. 10, p. 291.

Bukry, D., 1973. Coccolith stratigraphy, Eastern Equatorial Pacific, Leg 16. In van Andel, Tj. H., Heath, G. R. et al. Initial Reports of the Deep Sea Drilling Project, Volume XVI. Washington (U. S. Government Printing Office).

Bukry, D., Douglas, R. G., Kling, S. A. and Krasheninnikov, V., 1971. Planktonic microfossil biostratigraphy of the northwestern Pacific Ocean. In Fisher, A. G., Heezen, B.C. et al., Initial Reports of the Deep Sea Drilling Project, Volume VI. Washington (U.S. Government Printing Office), p. 1253-1300.

Martini, E., 1971. Standard Tertiary and Quaternary calcareous nannoplankton zonation. Plankt. Conf. 2nd., Rome, 1970, Proc., p. 739.

Perch-Nielsen, K., 1969. Die Coccolithen einger Dänischer Maastrichtien und Danienlokalitaten. Bull. Geol. Soc. Denmark. 19 (1), 51.

Thierstein, H. R., 1971. Tentative Lower Cretaceous calcareous nannoplankton zonation: Eclogae Geol Helvetiae., v. 64. 


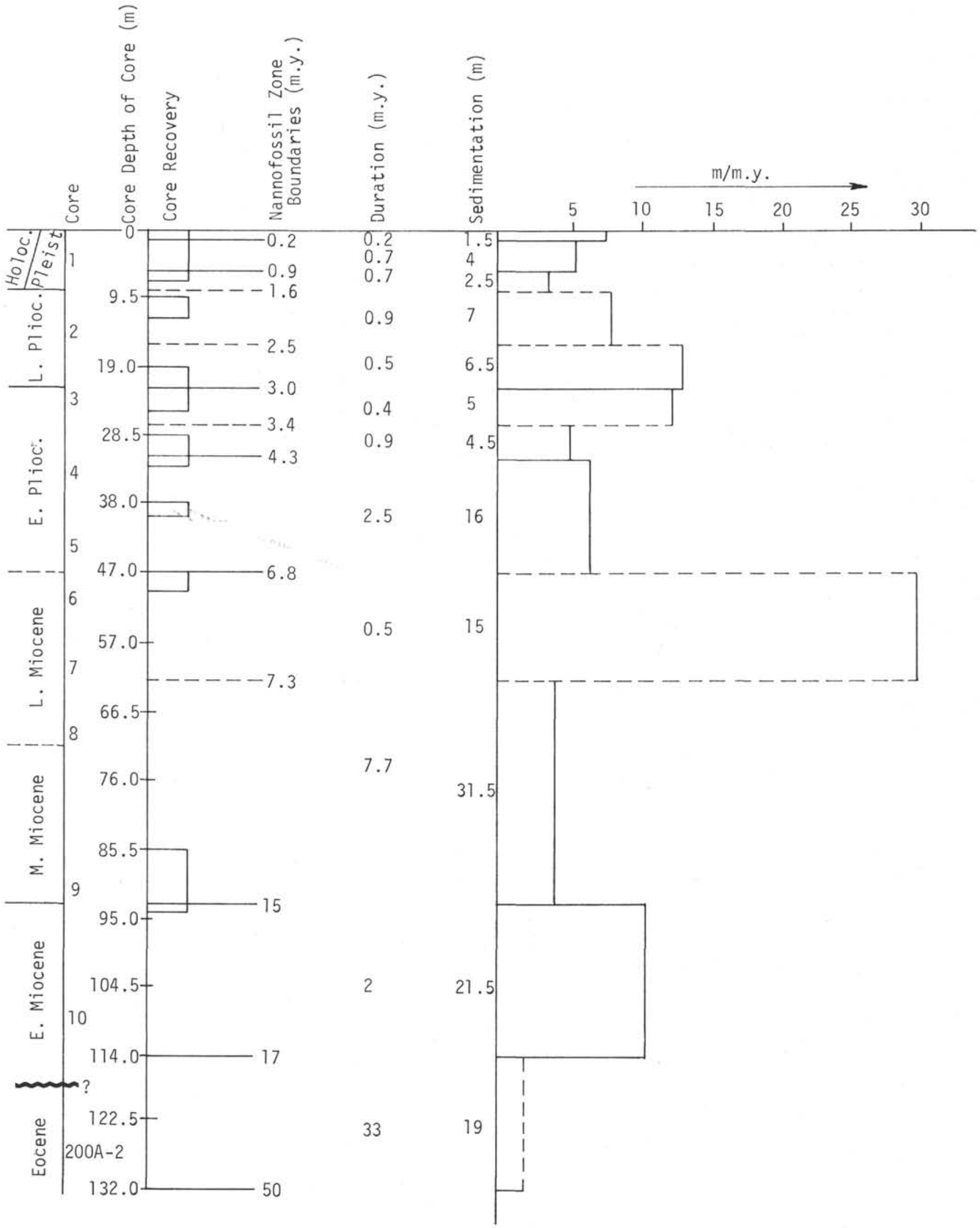

Figure 6. Sedimentation rate changes in Hole 200. 


\section{PLATE 1}

Early Cretaceous Coccoliths from Holes 195 and 196 and Ceratolithus from Ita Mai Tai Seamount Hole 200.

(all photomicrographs $\times 2500$ )

Figure 1

Figure 2

Figure 3

Figure 4

Figure 5

Figure 6

Figure 7

Figure 8

Figure 9

Figure 10

Figure 11

Figure 12

Figure 13

Figure 14

Figure 15

Figure 16

Figure 17

Figure 18

Figure 19

Figure 20

Figure 21
?Zygodiscus sp. Hole 196, Core 3, core catcher.

Same specimen as Figure 1; phase contrast.

Stephanolithion laffittei Noël. Hole 196, Core 3, core catcher.

Biantholithus sp. aff. B. sparsus Bramlette and Martini. Hole 196, Core 3, core catcher.

Same specimen as Figure 4; polarized light.

'Cretarhabdus crenulatus Bramlette and Martini', sensuThierstein, 1971. Hole 196, Core 3, core catcher.

Markalius circumradiatus (Stover); phase contrast. Hole 195, Core 4, center-bit sample.

Same specimen as Figure 7.

Cruciellipsis cuvillieri (Manivit). Hole 195A drill-bit sample at 383 meters.

?Rucinolithus sp. Hole 196, Core 3, core catcher.

Same specimen as Figure 10; different focus.

Ceratolithus amplificus Bukry and Percival. Hole 200, Core 4, Section 1 (bottom).

Same specimen as Figure 12; polarized light.

Ceratolithus sp. aff. C. cristatus Kamptner. Hole 200, Core 1, Section 4 (bottom). Lateral view with well-developed toothplate.

Ceratolithus primus Bukry and Percival. Hole 200, Core 5, Section 1 (bottom).

Ceratolithus primus Bukry and Percival. Hole 200, Core 4, Section 1 (bottom).

Ceratolithus bizzarus Bukry. Hole 200, Core 4, Section 2 (bottom).

Ceratolithus rugosus Bukry and Bramlette. Hole 200, Core 1 , Section 3 (bottom).

Ceratolithus rugosus Bukry and Bramlette. Phase contrast. Hole 200, Core 1, Section 4 (bottom).

Ceratolithus rugosus Bukry and Bramlette. Hole 200, Core 2, Section 2 (bottom).

Same specimen as Figure 20; polarized light. 


\section{PLATE 1}
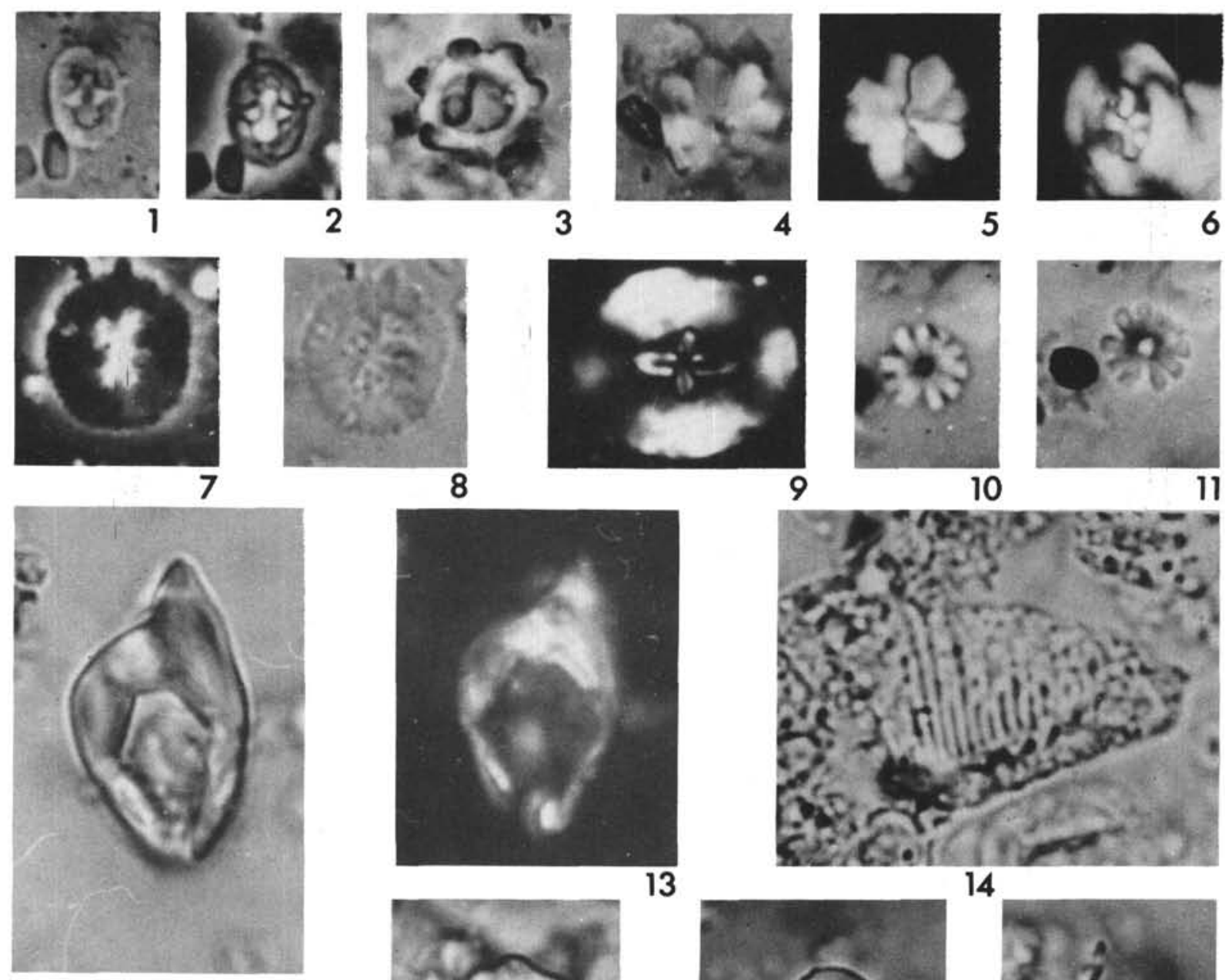

11

12
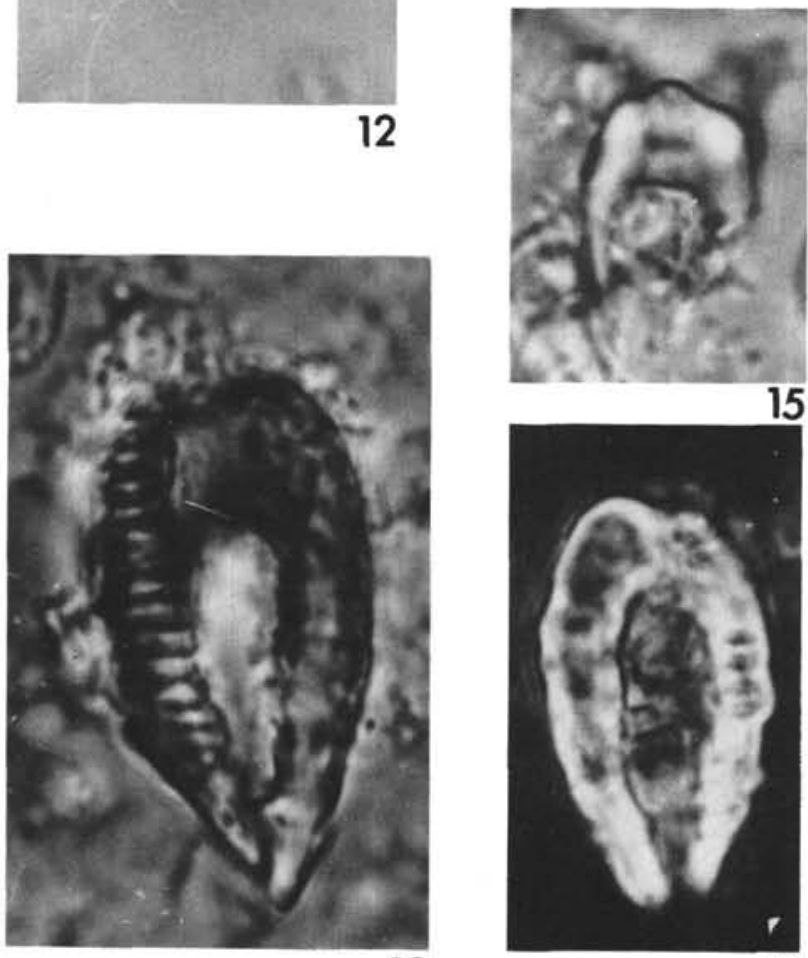

13

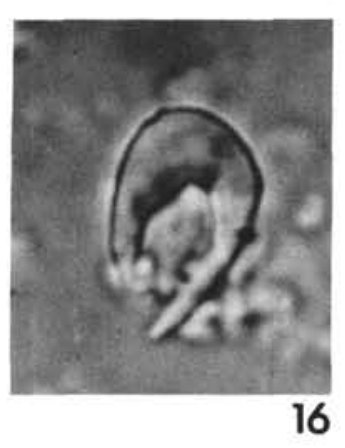

14

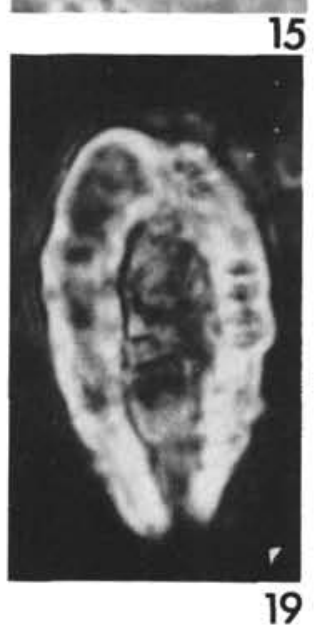

15

16
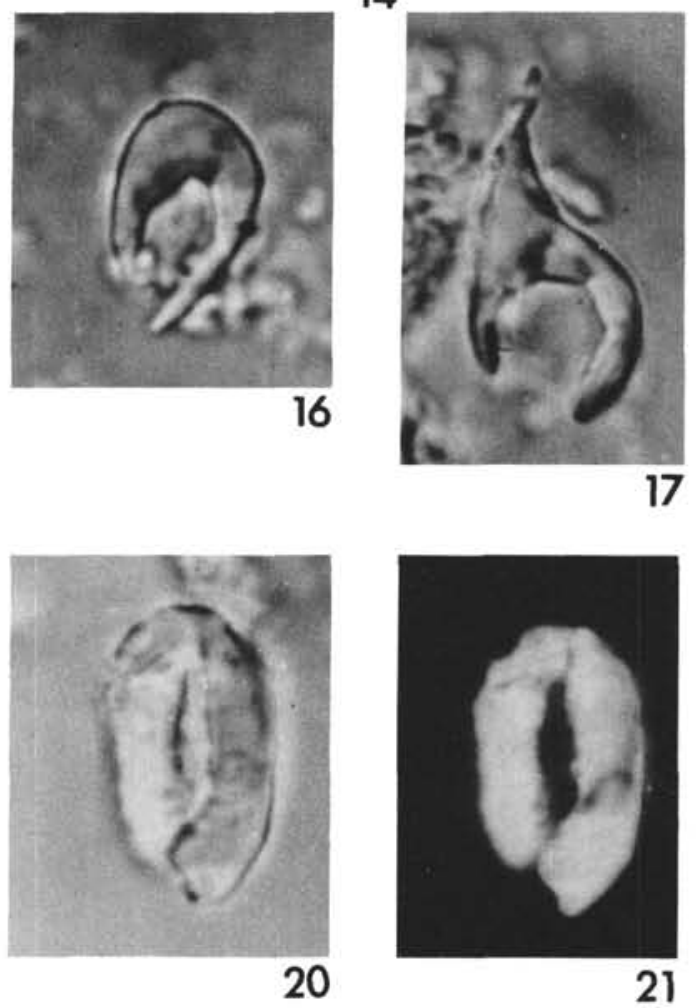


\section{PLATE 2}

Discoaster and Scyphosphaera from Ita Mai Tai Seamount (all photomicrographs $\times 2500$ )

Figure 1

Figure 2

Figure 3

Figure 4

Figure 5

Figure 6

Figure 7

Figure 8

Figure 9

Figure 10

Figure 11

Figure 12

Figure 13

Figure 14

Figure 15
Discoaster dilatus Hay. Hole 200, Core 4, Section 2 (bottom).

Discoaster dilatus Hay. Hole 200, Core 9, Section 4 (bottom).

Discoaster dilatus Hay. Hole 200, Core 9, Section 6 (bottom).

Discoaster surculus Martini and Bramlette. Hole 200, Core 3, Section 1 (bottom).

Discoaster sp. aff. D. formosus Martini and Worsley. Hole 200, Core 3, Section 3 (bottom).

Discoaster sp. aff. D. formosus Martini and Worsldy. Hole 200, Core 3, Section 3 (bottom); median focus.

Same specimen as Figure 6; focus on central knob.

Discoaster exilis Martini and Bramlette. Hole 199, Core 2, Section 6 (bottom).

Discoaster surculus Martini and Bramlette. Hole 200, Core 3, Section 3 (bottom); overcalcified, triradiate form.

Discoaster sp. Hole 200, Core 9, Section 2 (bottom); overcalcified form of $D$. deflandrei?

Discoaster hamatus Martini and Bramlette. Hole 200, Core 6, core catcher.

Discoaster neorectus Bukry. Hole 200, Core 5, Section 1 (bottom).

Scyphosphaera globulata Bukry and Percival. Hole 200 , Core 3, Section 2 (bottom); side view, median focus.

Scyphosphaera globulata Bukry and Percival. Hole 200 , Core 3, Section 2 (bottom); side view, surface focus.

Scyphosphaera globulata Bukry and Percival. Hole 200, Core 3, Section 3 (bottom); top view. 
PLATE 2
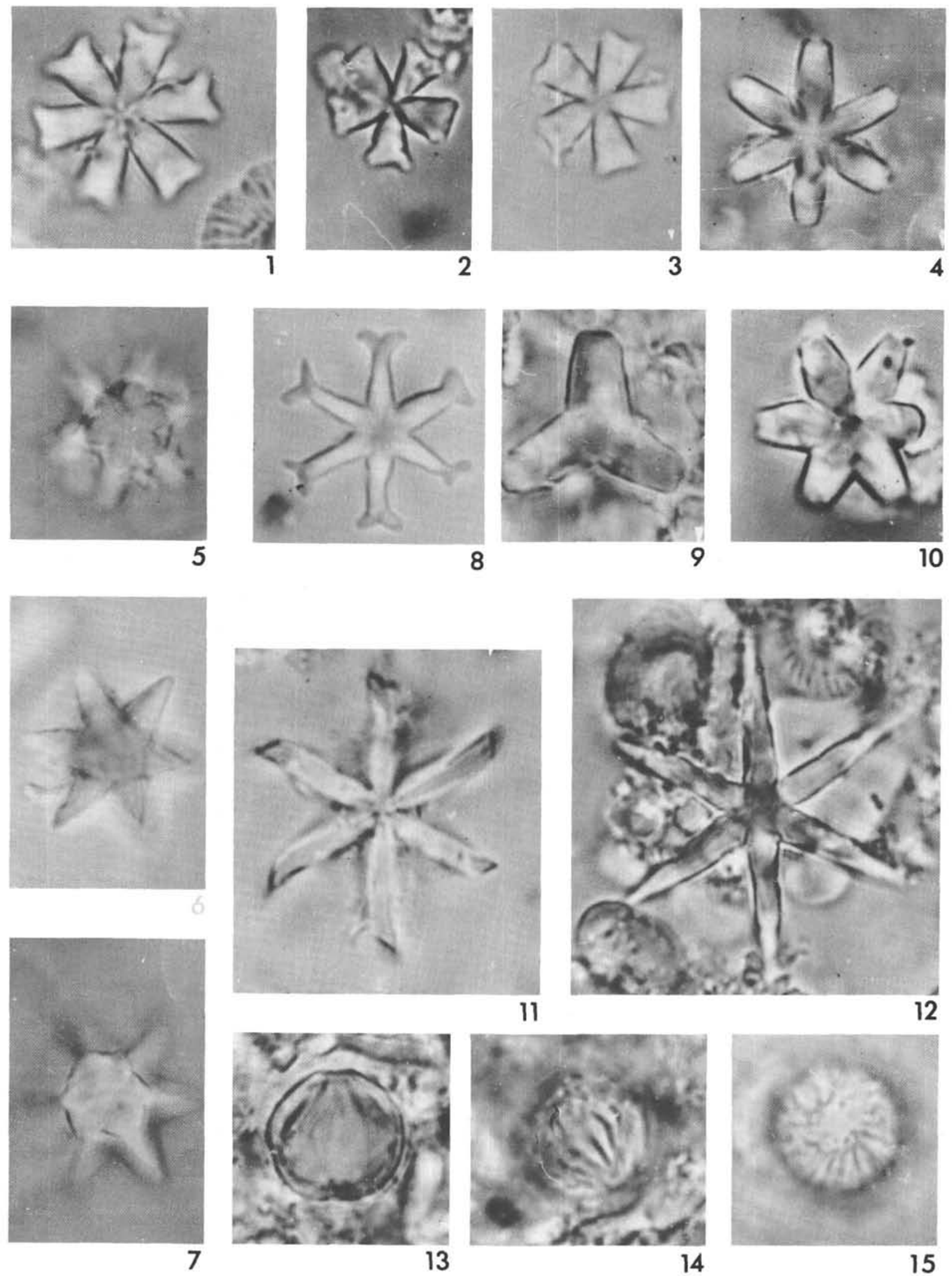

0
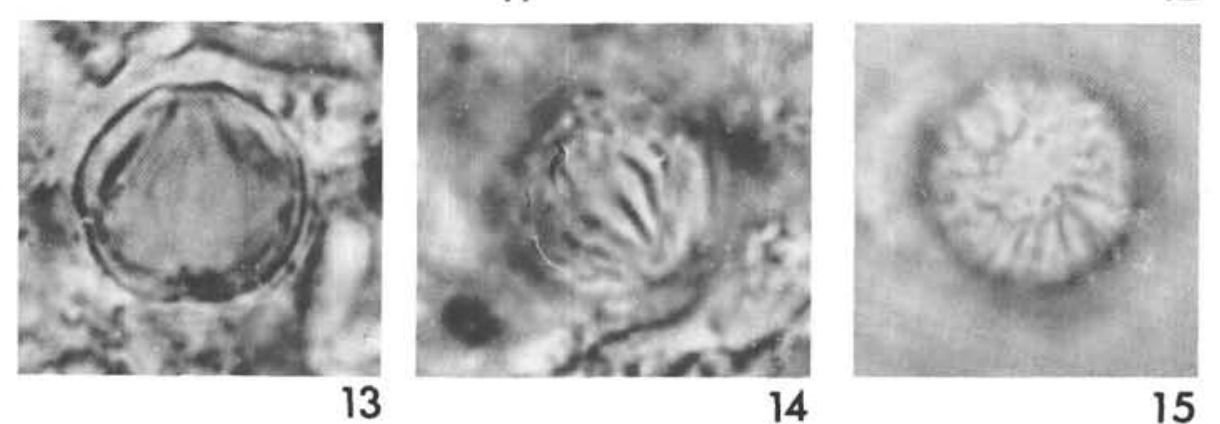


\section{PLATE 3}

Spenolithus from Ita Mai Tai Seamount, Cribrosphaerella and Fasciculithus from Hole 199

(all photomicrographs $\times 2500$ )

Figure 1

Figure 2

Figure 3

Figure 5

Figure 6

Figure 7

Figure 8

Figure 9

Figure 10

Figure 11
Sphenolithus heteromorphus Deflandre. Hole 200, Core 9, Section 2 (bottom); long-spined form, spine orientation perpendicular to polarization plane.

Sphenolithus heteromorphus Deflandre. Hole 200, Core 9, Section 2 (bottom); short-spined form.

Cribrosphaerella ehrenbergii (Arkhangelsky). Hole 199, Core 11, Section 1 (92 cm). Asymmetric tear-drop form; similar forms are also known from the genus Nephrolithus.

Same specimen as Figure 3; polarized light.

Fasciculithus sp. aff. F. mitreus Gartner. Hole 199, Core 10 , Section $2(21 \mathrm{~cm})$; etched; and recrystallized specimen.

Sphenolithus heteromorphus Deflandre. Hole 200, Core 9, Section 1 (bottom); long-spined form.

Same specimen as Figure 6; polarized light.

Sphenolithus heteromorphus Deflandre. Hole 200, Core 9, Section 6 (bottom).

Sphenolithus heteromorphus Deflandre. Hole 200, Core 9, Section 2 (bottom); electronmicrograph $\times 10000$.

Same specimen as Figure 8; polarized light.

Sphenolithus hetermorphus Deflandre. Hole 200, Core 9, Section 2 (bottom); long-spined form, electronmicrograph $\times 15000$. 
PLATE 3
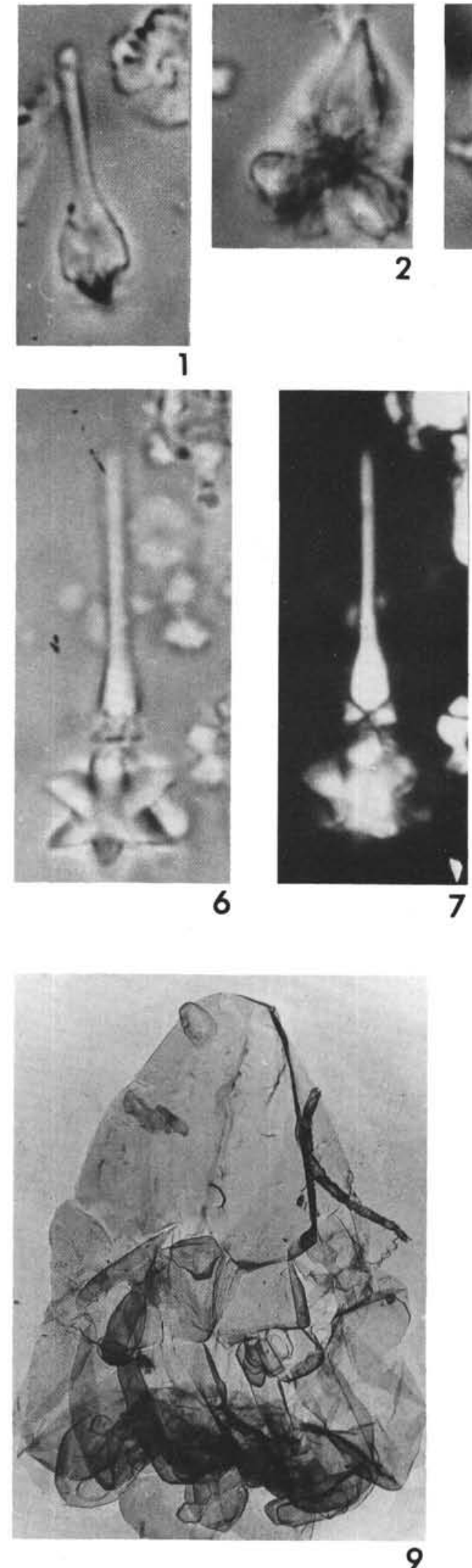
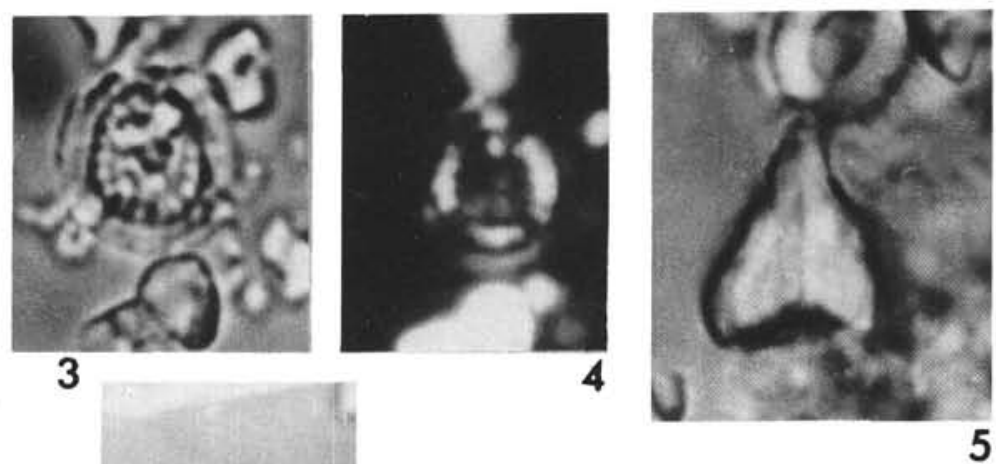

5
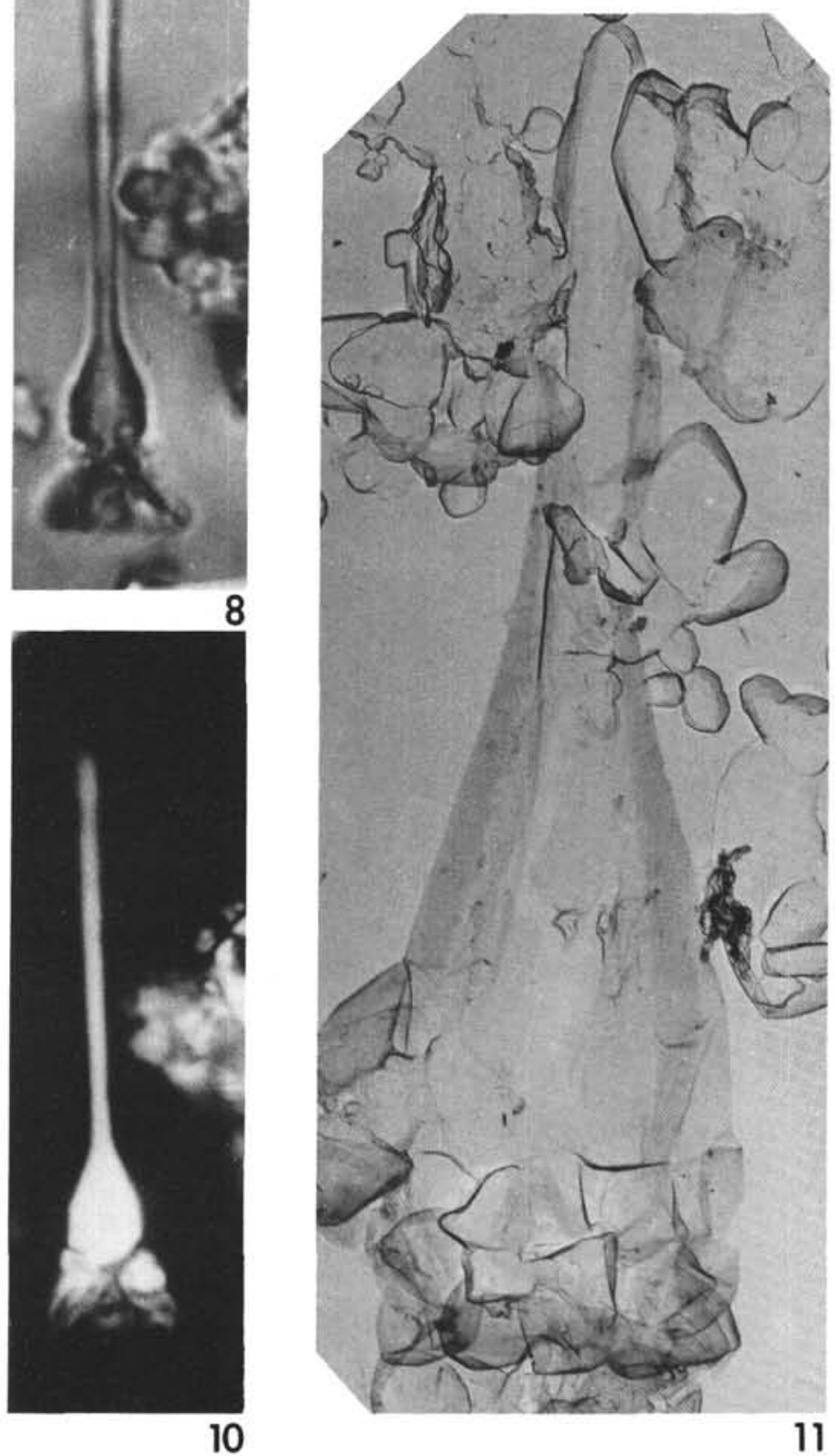


\section{PLATE 4}

Helicopontosphaera and Scyphosphaera from Ita Mai Tai Seamount (all photomicrographs $\times 2500$ )

Figure 1 Helicopontosphaera granulata Bukry and Percival. Hole 200, Core 9, Section 2 (bottom); electronmicrograph $\times 20000$.

Figure 2 Helicopontosphaera granulata Bukry and Percival. Hole 200, Core 3, Section 3 (bottom).

Figure 3 Same specimen as Figure 2; polarized light.

Figure 4 Helicopontosphaera granulata Bukry and Percival. Hole 200, Core 5, Section 1 (bottom).

Figure 5 Scyphosphaera sp. Hole 200, Core 2, Section 1 (bottom); median focus.

Figure 6 Same specimen as Figure 5; surface focus.

Figure 7 Scyphosphaera pulcherrima Deflandre. Hole 200, Core 2, Section 2 (bottom).

Figure 8 Scyphosphaera pulcherrima Deflandre. Hole 200, Core 2, Section 1 (bottom); polarized light. 
PLATE 4

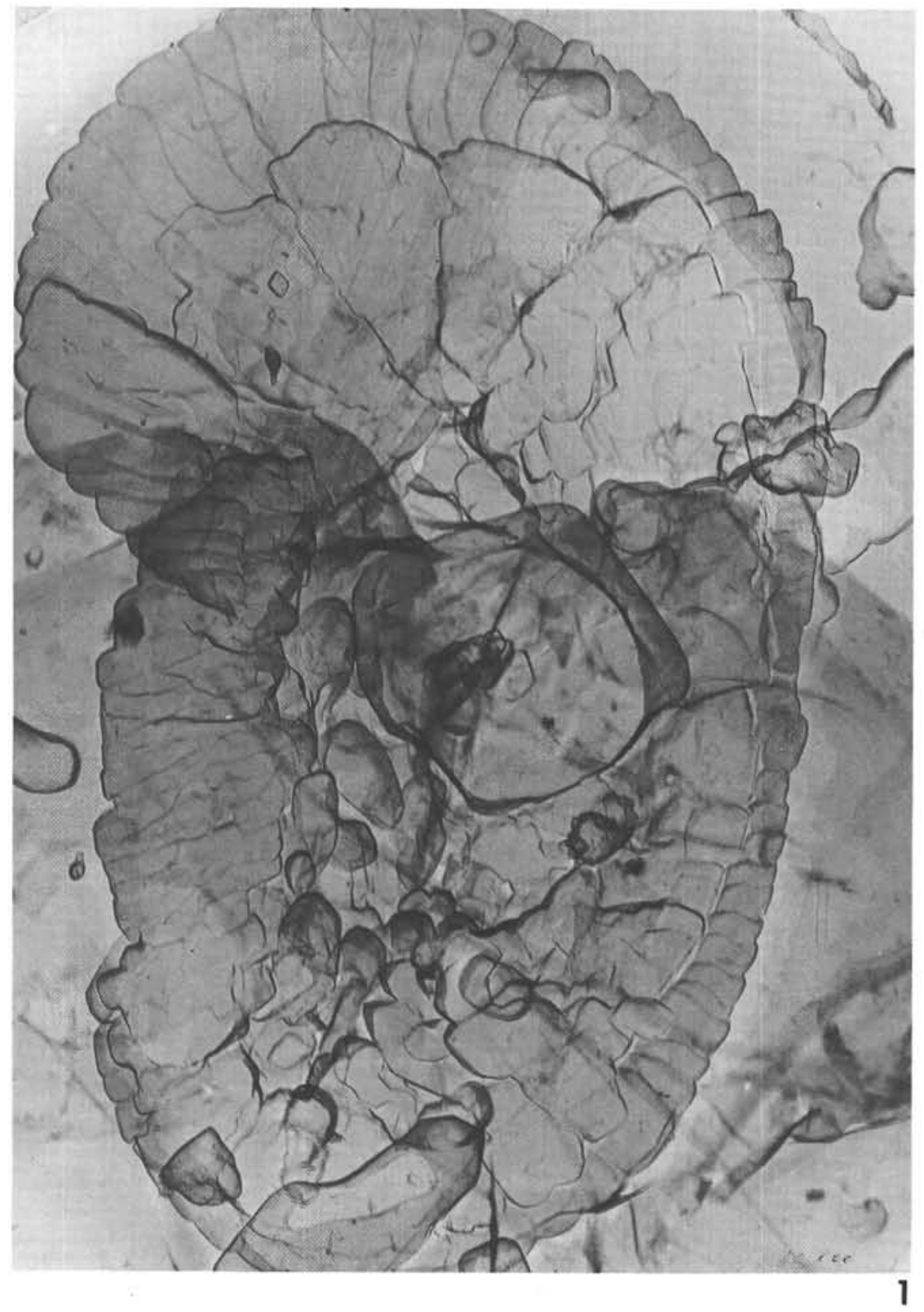

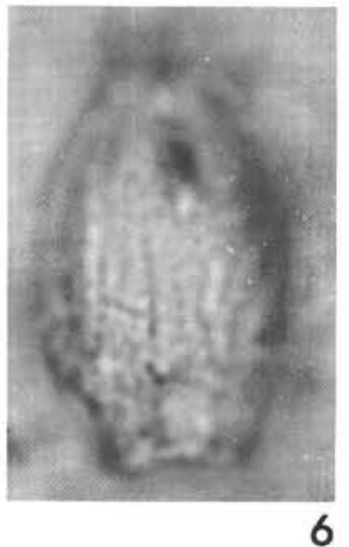

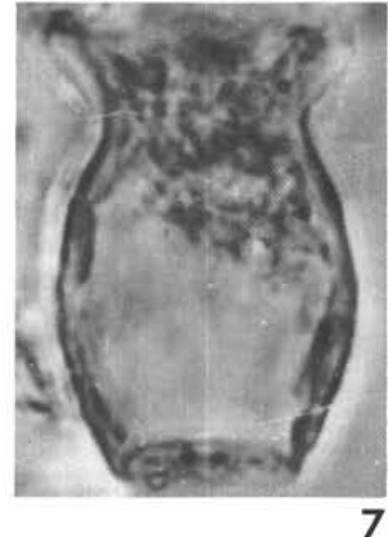

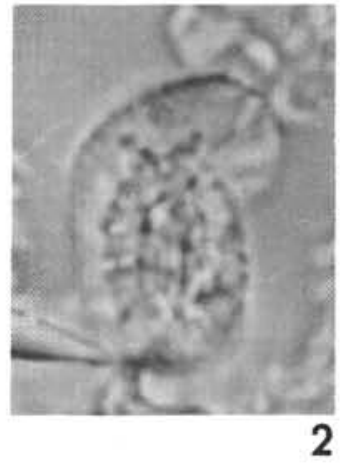
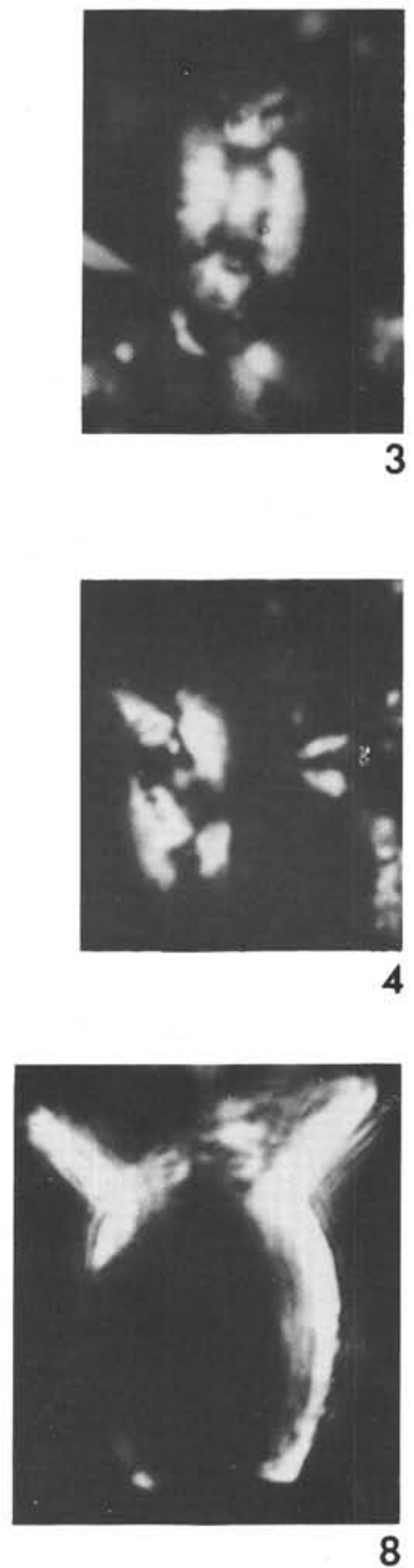


\section{PLATE 5}

Cyclococcolithina and Thoracosphaera from Ita Mai Tai Seamount. (all photomicrographs $\times 2500$ )

Figure 1 Cyclococcolithina macintyrei (Bukry and Bramlette). Hole 200, Core 1, Section 1 (bottom).

Figure 2 Cyclococcolithina macintyrei (Bukry and Bramlette). Hole 200, Core 3, Section 3 (bottom).

Figure 3 Cyclococcolithina leptopora (Murray and Blackman). Hole 200, Core 3, Section 3 (bottom); isolated proximal shield, electronmicrograph $\times 10000$.

Figure 4 Thoracosphaera sp.; spinate form. Hole 200, Core 2, core catcher.

Figure 5 Same specimen as Figure 4; polarized light. 


\section{PLATE 5}
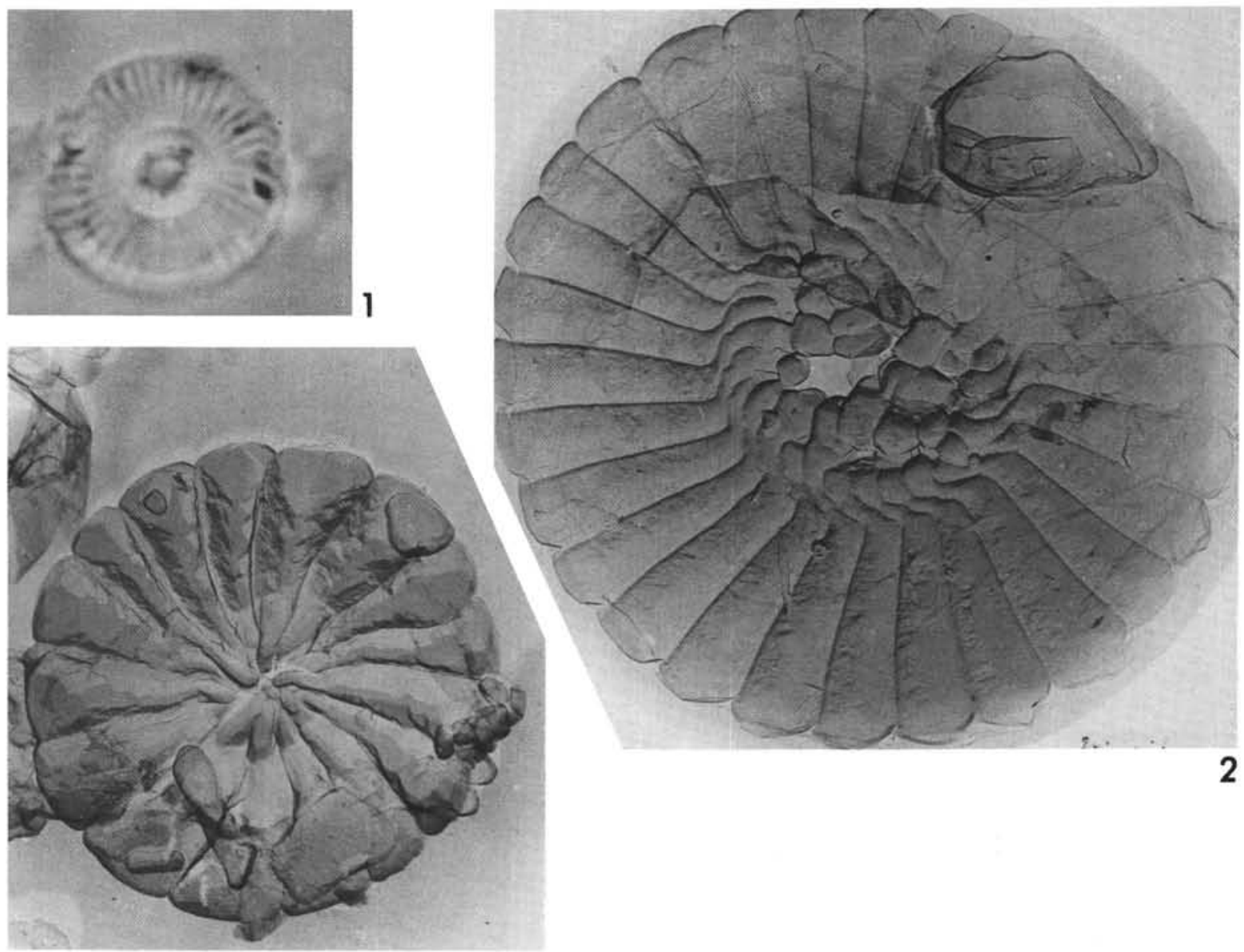

\section{3}
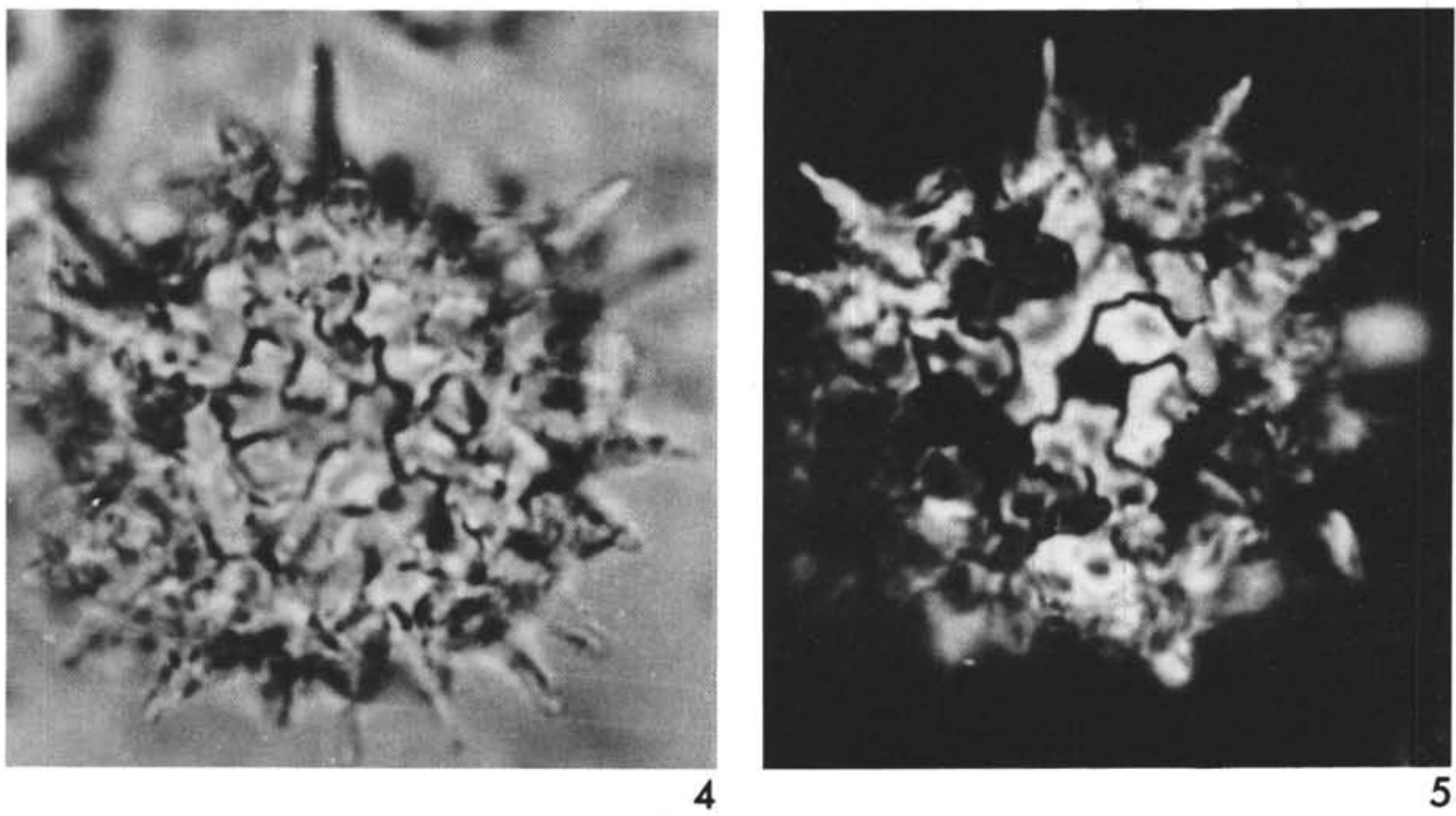
PLATE 6

Coccoliths from Ita Mai Tai Seamount

(all light micrographs $\times 2500$ )

Figure 1

Figure 2

Figure 3

Figure 4

Figure 5

Figure 6

Figure 7
Emiliania ovata Bukry. Hole 200, Core 3, Section 3 (bottom); electronmicrograph $\times 30000$.

Coccolithus doroconoides Black and Barnes. Hole 200, Core 1, Section 1 (bottom); electronmicrograph $\times 10000$

Emiliania ovata Bukry. Hole 200, Core 1, Section 1 (bottom); phase contrast.

Emiliania annula (Cohen). Hole 200, Core 4, Section 2 (bottom).

Emiliania ovata Bukry. Hole 200, Core 1, Section 1 (bottom); polarized light.

Gephyrocapsa caribbeanica Boudreaux and Hay. Hole 200, Core 1, Section 1 (bottom); electronmicrograph $\times 10000$.

Cyclococcolithina sp. aff. C. leptopora (Murray and Blackman). Hole 200, Core 1, Section 1 (bottom); electronmicrograph $\times 10000$ (similar to C. foliosa Kamptner). 


\section{PLATE 6}
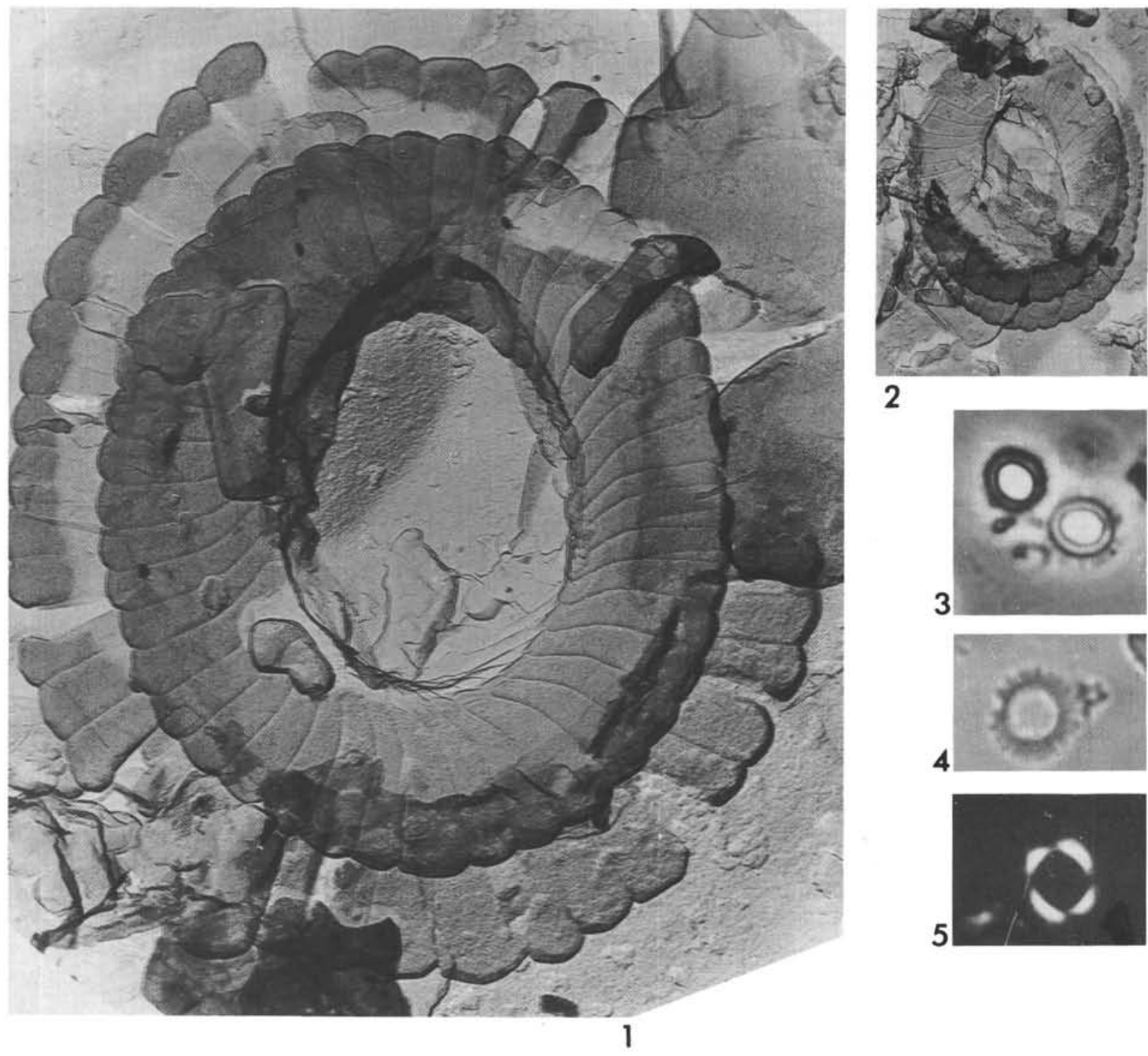

2
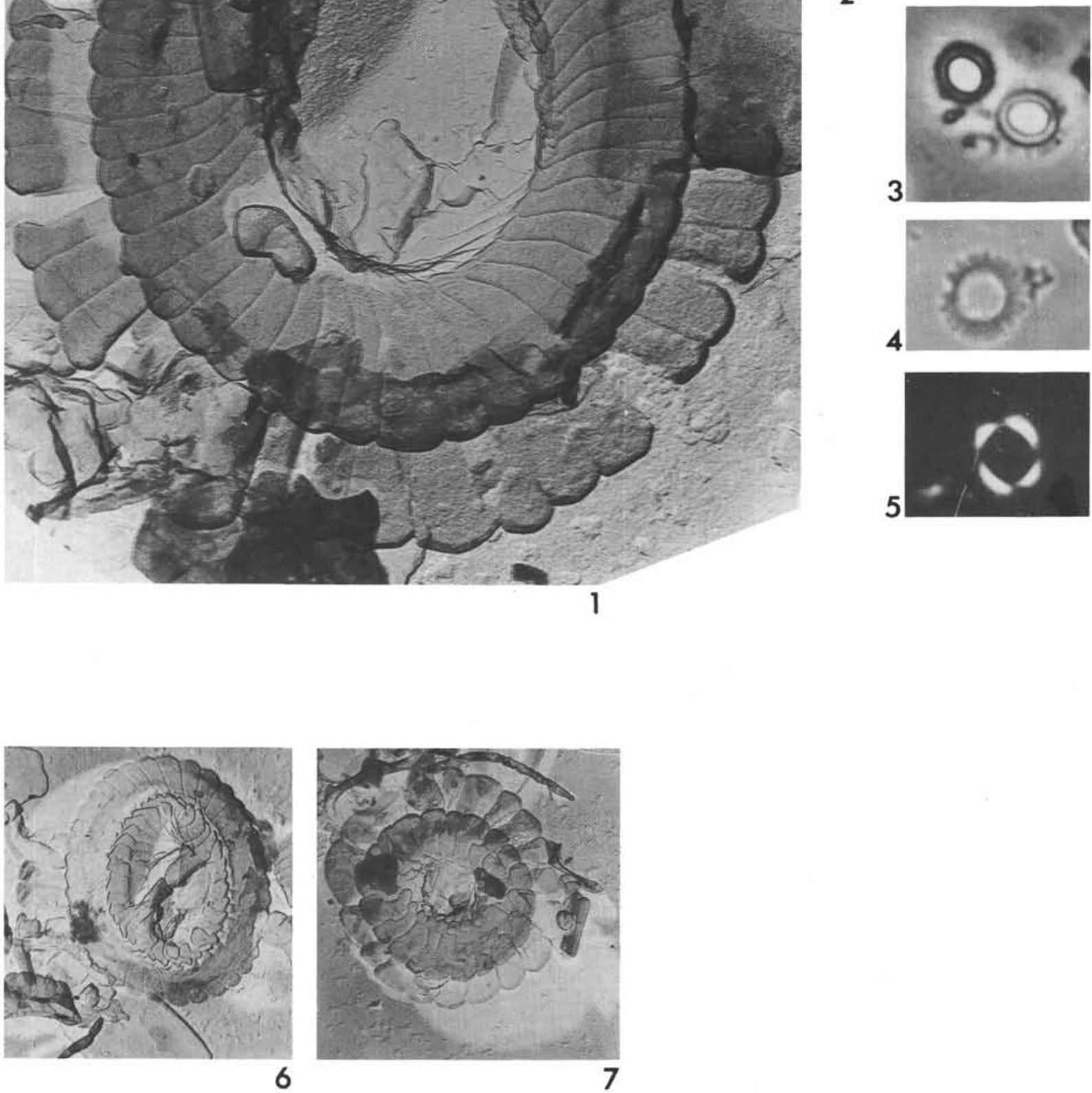